\title{
Obscenity and Censorship in the Reign of Henri III
}

\section{Jonathan Patterson, St Hilda's College, University of Oxford}

\begin{abstract}
The Parisian Pierre de L'Estoile was an obsessive compiler of politically motivated, obscene ephemera in the reign of King Henri III (1574-89). This article explores how and why L'Estoile kept on adding to a vast archive of vile materials that he purportedly despised. Examining L'Estoile's manuscripts at close quarters, the article traces a complex practice of censure and self-censorship alongside similar practices by contemporary writers (Henri Estienne and Pierre de Brantôme). L’Estoile's contribution to the history of sexuality is that of a self-aware critic, legitimating his inability not to disavow the obscenities he has chosen to preserve.
\end{abstract}

\section{ACKNOWLEDGEMENTS}

This article grew out of a conference paper given at the Renaissance Society of America Annual Meeting, 2016. Exchanges thereafter with Timothy Chesters, Raphaële Garrod, Michael Meere, Roy Norton, Jennifer Oliver, Jonathan Parkin, and Phillip Usher all helped me refine my arguments and ideas. Neil Kenny and Wes Williams graciously improved subsequent drafts, as did the Editor of Renaissance Quarterly and three anonymous reviewers. Special thanks go to Hugh Roberts and to Tom Hamilton for their insights, expertise and practical guidance, without which my understanding of Pierre de L'Estoile and Renaissance obscenity would be much the poorer. Unless otherwise stated, all translations from French and Latin are my own. 


\section{Introduction}

The Parisian Pierre de L’Estoile (1546-1611) lived through one of the most turbulent periods in the history of France: the Wars of Religion (1562-98). He left an extraordinarily rich testimony of this period, a burgeoning collection of documents detailing all sorts of corruption he perceived in excessive quantities all around him. L'Estoile spent much of his career as an audiencier in the Chancery attached to the Parlement de Paris. The office was not particularly prestigious in itself. It nonetheless enabled him to build up a web of contacts in both the Royal Court based at the Louvre, and in the nearby Palais de Justice. Availing himself of his links to France's legal, social and political hubs, L'Estoile ensured that he kept abreast of all the latest news, pamphlets, poetry and gossip that might shape the nation's future. This article considers a fraction of L'Estoile's vast archive of ephemera dating from the chaotic reign of King Henri III (r.1574-89). It seeks to interrogate L'Estoile’s motives and strategies for obsessively extending his collection of obscene material, ${ }^{1}$ and the differing ways he sought critical distance from it, in the two extant manuscripts of his Registre-journal du règne de Henri III drafted in the years c.1589-1606. ${ }^{2}$

L’Estoile’s Registre-journal has often been mined by historians and literary specialists as a useful source of supplementary information for their inquiries. In recent years, however, a growing number of scholars have begun to study his works in their own right - a development considerably advanced by the modern six-volume Registre-Journal du règne de Henri III of Madeleine Lazard and Gilbert Schrenck. ${ }^{3}$ The present study is indebted to the Lazard-Schrenck edition, which painstakingly reproduces and differentiates between the two surviving recensions (labelled [A] and [B]) of L’Estoile’s text. ${ }^{4}$ L'Estoile’s writing evolved considerably over time. It took form in the 1570s as register of notable happenstances not unlike other period diaries; but by the 1600s it had metamorphosed into a much more 
sophisticated project, subject to ongoing redrafting, that was as much about preserving a personal memory as it was about collective mentalities. ${ }^{5}$

This article seeks to cast new light on the evolving, subjective nature of L'Estoile's process of compilation: a process understudied in scholarship on L'Estoile and his apparently impersonal, detached engagement with the obscene. For all its considerable qualities, the Lazard-Schrenck edition (as its editors acknowledge) cannot reproduce all aspects of the original manuscripts on which it is based. Using the tools of close textual and manuscript analysis, I shall interrogate afresh L'Estoile’s transcription techniques, and what they reveal about his emotional investment in his writing. L'Estoile came to see his Registre-journal as a kind of historical record, governed by a Tacitean obligation to tell the truth in all its horrible fullness about period he is documenting. ${ }^{6}$ In this regard, his work constitutes a vital - and in many cases the only - surviving documentation of ephemera from the reign of Henri III, so much of which was destroyed in the reign of Henri IV. L'Estoile was especially attentive to lessons that may be drawn from the public view of flawed rulers - as long as it was recorded “discreetly, sincerely, dispassionately and after their death."7 These caveats notwithstanding, L'Estoile regularly commented upon his compiled materials in severe moralistic tones, reacting vehemently against that which, by Christian standards, could be construed as vile and scandalous. Such vigorous displays of disgust thus require careful unpacking, if one is to understand what motivated them and to whom they were particularly directed.

My argument reposes primarily on materials copied into the Registre-journal dating from the period 1577-81. Examining at close quarters a series of sexually explicit texts that L'Estoile deemed vile, scandalous and malicious, I shall trace the emergence of a form of transtexuality (in Gérard Genette’s terms), ${ }^{8}$ foregrounding, overtly or covertly, the distinctiveness of the memorialist's own writing from other texts interpolated in his manuscripts. L'Estoile sought mastery over his vile materials according to what might be 
called an "art of containment,” as conceptualized by Antónia Szabari following Tom Conley. ${ }^{9}$ This art found its expression across the $[\mathrm{A}]$ and $[\mathrm{B}]$ recensions of the Registrejournal through a varied practice of censure (moral pronouncements) and self-censorship (deliberate deletion of material previously transcribed), ${ }^{10}$ as if to communicate an idiosyncratic aloofness from dangerous, defamatory, and lewd materials and ideas. I shall test L'Estoile's distinctiveness in this respect via comparison with the self-censoring tactics of two contemporaneous writers, Henri Estienne and Pierre de Brantôme, who, like L'Estoile, fully immersed themselves in the transmission of obscenities by partial disavowal.

In all three cases, and especially L'Estoile's, the art of containment had a significant socio-cultural element, a continual (re)negotiation of the author's stance vis-à-vis his anticipated readership. L’Estoile practiced “social privacy.” Writing in his secluded cabinet was not a hermetic act of isolation, and it did not preclude the exchange of news, pamphlets, poetry and manuscripts with a select group of intimates. ${ }^{11}$ These included like-minded journal writers (Laurent Bouchel), erudite compilers (Pierre Dupuy, Thomas Sébillet, Claude de Marteau), and printers (Fédéric Morel): in short, a network of semi-distinguished parliamentarians and scholars with wide-ranging interests (especially in classical literature) among whom L'Estoile sought to maintain a credible voice. ${ }^{12}$ And yet, L’Estoile manifested signs of deep discomfort at the obscene materials he helped to circulate through his ever widening circle of contacts. A double game seems to be in operation here, whereby the memorialist impresses upon his readers the importance of both exposing and suppressing the obscene - even to the extent of openly attacking those who allegedly authored it. To shed new light on L'Estoile's intentions, it will be necessary to reflect on how he continually varies his distance from his vile materials. Crucially, I shall argue, L’Estoile achieves differing degrees of disavowal through both verbal and non-verbal techniques of persuasion. Incorporating rigid censoriousness as well as a much looser, almost ludic form, his art of 
containing the vile acquires a degree of complexity that close reading is best placed to capture.

\section{Disowning priapic poetry}

In his account of the first three years of Henri III's reign, L’Estoile records ephemeral material on sexual indecencies in an ambivalent tone - never fully involved, and yet some distance from neutral. A case in point may be found in his coverage of September 1577, which shows him dabbling in the Parisian gossip surrounding the marriage of one Estienne de Bray to the daughter of the Damoiselle de Corbie: a society wedding where the chief attraction, as far as the tattlers were concerned, was the groom's impotence. L'Estoile is prepared to go along with the sordid banter - but only up to a point. With his habitually nonchalant collector's boast, he tells his readers how he came into possession of several pasquinades, jests and sonnets deriding Bray’s unfortunate condition. These conveniently fell into his hands, ${ }^{13}$ or so he claims, speaking of eight transcribed offerings selected for their unkind jokes about Bray facing the embarrassing prospect of an unconsummated union. According to L'Estoile, these witty poems made for humorous conversation among good company and merry spirits. ${ }^{14}$ But then comes a ninth poem, entitled Jan qui ne peult (John Who Can't), which is altogether more salacious:

By what new horror, what misfortune strange

Has fate now banished me far from the joy

Awaiting me this night there by her side

Who burns like me with a requited love! ...

My prick lies clueless, flabby, just exactly 
Like some dead beast's carelessly-folded tripes.

To sum up, he's no use: sad, coward wretch...

Flat, floppy, dreary, shaking, weak, and feeble.

So now to make you stand, my prick, it takes,

A two-toothed ancient...

A drooling cunt and mangy, ratty and skinny too,

Wrinkled and wide, slummy and ulcerate. ${ }^{15}$

Did L'Estoile record this piece because he particularly enjoyed its bravura offering of bawdy humor? It seems a distinct possibility that he did. Modern critics have argued that Jan qui ne peult is something of a virtuoso performance in imitating the long traditions of impotence literature, namely, a twin focus on bewailing the affliction and comic attempts to regain sexual prowess. ${ }^{16}$ Various literary interpretants (to use Kathryn Gravdal’s term), ${ }^{17}$ lend structure to this obscene poem of 74 lines. As Roger Kuin and Anne Lake Prescott have demonstrated, the author of Jan qui ne peult seems well versed in the disgusting elements of Horace (Epodes 8 and 12), Ovid (Amores III.7) and Petronius (Cena Trimalchionis), as he goes about detailing an impotent man's dismay at being unable to satisfy his lover. Echoes of these Roman satirists may be heard in Jan's lamenting his bad stars; in the description of the young, willing and attractive bedmate; in images of the wrinkled, flaccid penis, duly cursed by the narrator; and in the evocation of an old woman afflicted by the stench of body odor and vaginal discharge. ${ }^{18}$ Arguably the poet also has in his sights more recent French and Italian traditions. Jan’s lover's shapely breast - “a firm round breast pointed with strawberry”19 - irresistibly recalls Clément Marot’s famous Blason du beau tetin (1535), itself echoing the angelic breast of Petrarch’s Laura. ${ }^{20}$ Lastly, the lurid allusions to the old hag’s withered, drooling nether regions form a vile parallel with the formless, oozing, 
sagging, scrawny breast described by Marot in his Blason du laid tetin (1538) - a counterblason to that which lauded the angelic breast. $^{21}$

The Renaissance poetic community was not easily shocked by descriptions like this of sex in all its close-up, even grotesque corporeality. Poets wishing to depict such matters could (and did) point to the lex Catulliana: the notion, deriving from Catullus and echoed by Martial and others, that as long as a poet was generally held to be upright, he could occasionally indulge in lascivious verse without tarnishing his reputation or his readers' consciences. ${ }^{22}$ L'Estoile, however, invokes no such principle to inform his readers' reception of Jan qui ne peult. Quite the reverse: these obscene literary parodies, however slickly done, should not be allowed to pass without stern censure. He duly introduces the poem with a strongly cautionary remark: what readers are about to encounter, they must acknowledge, is “vile, lascivious, and grating on Christian ears.” ${ }^{23}$ L'Estoile, it would seem, is now no longer well disposed towards the theme of impotence, and warns his readers that the base humor of Jan qui ne peult is far from harmless. Two further considerations support this warning: firstly, certain political undercurrents within the poem, and secondly, further supervening censure on the part of the memorialist.

In the first instance, the reader's attention is drawn to the Gallic "cock" sketched in lines 27-28 of Jan qui ne peult as an heroic counterpoint to Jan’s limp member. On this reading, the entire poem bears a nostalgic yearning for France's chivalrous past, the age of Joan of Arc, “The Maid of Orleans” (line 40). However, the Gallic cock, that gallus representing Gallia (i.e. France) is now crestfallen under the rule of Henri III; ${ }^{24}$ it has no more potency or desire for conquest than Jan’s fearful “coward” (line 37), which, by its lack of masculine seed, also wittily evokes the galli of old, the castrated priests of Cybele, mocked by Roman poets as half-men. Such imagery reflects the increasingly vexatious problem of the king's masculinity, deeply questionable as it was to contemporary observers. 
Henri had exhibited regal promise as a young man; but since his accession to the French throne in 1574, his erstwhile military prowess had given way to certain fastidiousness, a taste for perfumed clothes, and a determination to prove himself as a peace negotiator rather than as a warrior. ${ }^{25}$ Seeking to portray himself as the very embodiment of Neoplatonic love and harmony, the occasionally cross-dressing, extravagant king created an alarming mix of power, politics and sexuality that he soon failed to control as all three elements became subject to unprecedented, relentless scrutiny. ${ }^{26}$ As such, the political subtexts in Jan qui ne peult are obtruding hints that the poet might be reaching out to like-minded readers regarding an "impotence” of government: one which, I shall argue, was visibly aggravated by the king's inability to produce an heir.

These hints about weak rule are developed by further commentary from L'Estoile, who notes that this kind of obscene literature was precipitously passing beyond manageable limits: no longer a source of private amusement handed around a circumspect company at the Palais de Justice, it had become a symptom of a corrupted age, rapidly spreading throughout Paris and beyond. The chief villain, as far as L'Estoile was concerned, was the man commonly held responsible for penning the vile piece in the first place: none other than Rémi Belleau (1528-77), “one of the learned and refined poets of our time.”27 Belleau, a friend of Pierre de Ronsard, and a fellow member of France’s premier coterie of poets - the Pléiade would have certainly possessed the necessary skill at imitation, although modern experts are divided as to whether he really was the author. ${ }^{28}$ For the purposes of the present study, what matters most is the reason L'Estoile gives for vilifying Belleau, namely that the latter yielded shamefully to the base temptations of fame in a corrupted age. For the memorialist, Belleau would not have enjoyed half his fame "if, following the example of his fellow poets, he had not soiled his muse with such and similar villainies."29 
Belleau, indeed, was by no means the only member of the Pléiade in L’Estoile’s sights. Nor was he the first poet L'Estoile associated with sexual impropriety. Previously, in both the Registre-Journal and in a separate miscellany of topical poems bearing the title Recueil divers de ce temps (Sundry Collection from the Present Age), ${ }^{30}$ he had recorded without explicitly condoning Huguenot ire against Etienne Jodelle (1532-73): a poet who was in the eyes of his Protestant opponents a godless heretic, given over to drink and lascivious verse. ${ }^{31}$ These latter accusations gained some substance from several lesser-known pieces of Jodelle’s large literary output. None of these are compiled in L'Estoile’s RegistreJournal; nor do they appear in his Recueil divers de ce temps. A number of them do however feature in an anonymous collection, entitled Bigarrures folatres et mesdisantes (Sprightly and Spiteful Miscellanea) which was closely linked to L’Estoile’s cabinet. ${ }^{32}$ In the Bigarrures folatres et mesdisantes, there is a notable emphasis on the male genitalia in a loose collection of sonnets attributed to Jodelle, laden with priapic imagery deriving from Petrarchan motifs. ${ }^{33}$ The collection continues in a similar vein, with a further, even more explicit offering, also ascribed to Jodelle: an Epitaphe du membre viril de Frere Pierre (Epitaph for the Virile Member of Brother Peter ${ }^{34}$ ), describing in copious detail the potent career of the "member" in question. This poem is then directly followed by a copy of Jan qui ne peult, attributed to Belleau, and prefaced by an almost identical moral health warning to that found in L’Estoile’s Registre-Journal. ${ }^{35}$ In the Bigarrures folatres et mesdisantes, a comic contrast thus arises from this phallic juxtaposition, from firm, fat and fleshy, to limp and floppy.

It seems likely that L'Estoile was aware of both the Jodelle and the Belleau poems, and of their potential for comic juxtaposition as demonstrated in the Bigarrures folatres et mesdisantes. One might consider his transcription of Jan qui ne peult in the Registre-Journal as another instance of such humor, with stern commentary deliberately inserted for the mirth of readers who share an indulgent, tongue-in-cheek attitude towards bawdy penis jokes. 
Nevertheless, I shall argue, the severe tone of L'Estoile's comments, when set in the wider context of his censuring practices, ultimately suggests otherwise. If L'Estoile expected the reader to be amused, he also showed an awareness of how bawdy literature was being put to new and much more sinister uses, on the cusp of a destructive wave of sexual polemic that would dog the monarch for the rest of his reign. As he revised his Registre-Journal, L'Estoile thus deliberately eschewed unguarded displays of obscenity. Conversely, he endeavored to highlight roles played by others, the likes of Jodelle and Belleau, thereby conveniently deflecting attention from his own ambiguous position in an insalubrious circuit of consumers of "bad poetry.” In foregrounding the scandal of Pléiade poets indulging in the obscene, L'Estoile was able to undermine their frequent boasts about championing the national literary cause. For L’Estoile, any such glory was worryingly ephemeral, dissipating into an irreversible “corruption” - moral and literary - that would become the hallmark of French poetry for the remainder of the sixteenth century.

\section{L'Estoile contra Ronsard}

The Registre-journal is unparalleled in its capacity for documenting this pervasive literary dissolution, whilst simultaneously developing strategies for containing it. A further example from a tumultuous month - April 1578 - serves to highlight L'Estoile’s increasingly diverse methods of recording the cacophony of irate voices rising against the monarch and those whom he appeared to have unjustly advantaged. Here one discovers the memorialist experimenting with different ways of delineating what he considered acceptable critiques of the king and his court from slanders which patently overstepped the moral line. As in the case of Jan qui ne peult, however, the passage from legitimate to lascivious condemnation was in 
some cases far from unequivocal - especially regarding L'Estoile’s own position vis-à-vis the vile materials he had so painstakingly transcribed.

The Peace of Bergerac (17 September 1577) created an uneasy hiatus between France's sixth and seventh Wars of Religion. During this period, the king's ability to institute lasting peace and order was subjected to vicious critiques. April 1578 stood out in L'Estoile’s mind as a particularly bad month: venality in the judiciary was rife, he complained, adding his voice to a chorus of calls for an overhaul of office-trafficking. ${ }^{36}$ Concluding a short summary of endemic corruption overriding orderly government, L'Estoile turns his attention to ephemeral literary responses against such "deformity." 37 Again his focus is on his acquiring diverse and proliferative poetic material from acquaintances. Again, moreover, his task is to signal to readers different levels of critique - whilst maintaining right down to the page layout an unmistakable trace of disorder.

This is best perceived in the later [B] recension of L'Estoile's diaries (fig. 1):

Here two distinct tendencies are in evidence. Firstly, two poems command attention in the centre of the page, since they are transcribed in a hand other than L'Estoile's. These are examples of estates satire which attack the two leading factions publically deemed most dangerous to France: the Italians promoted under the influence of the Queen Mother, Catherine de' Medici, and the king's court favorites, his mignons. ${ }^{38}$ The sonnets rely on commonplace tropes of an inverted political order: a realm whose government resides "not in the hands of a King, but in those of a vagabond woman” who has raised up “a Donkey as a man of justice.” ${ }^{39}$ The two poems also warn the monarch about promoting those who will not in any sense enhance his own glory, since they will inevitably use him merely as a means to further their own ambition. The sonneteer has no qualms about stressing the king's current political impotence, but is careful to frame this as a torpor from which he can rouse himself 
with the aid of the old guard: loyal warriors and impartial statesmen. This combination of piquant satire and plain exhortation against venality of offices strikes L'Estoile as fittingly representative of the nation's frustration.

Nonetheless, here one may also perceive an unusual development in L’Estoile's ordering of his material. The [A] recension had originally offered three further sonnets in a similar vein, lamenting the evil of civil war: a loss of integrity, loyalty and truthfulness across all tiers of French society, with a concomitant rise in blasphemy and violence. ${ }^{40}$ In the [B] recension, these sonnets have been scrapped in favour of a new triad, whose tone and language are strikingly more personal and injurious. Scrawled in the margins of [B] - in L'Estoile's own hand - is an untidy transcription of three more sonnets which reportedly speak of an individual's displeasure at seeing Henri's mignons steadily absorbing lucrative pensions and benefices. The vile sentiments expressed here saliently demonstrate how the king’s enemies seized upon popular doubts over his masculinity to condemn his largesse and favor as inescapably sexually and politically deviant. ${ }^{41}$

Historians now regard this process of promotion as a key political development of the late sixteenth century: by favoring sons of lesser provincial nobles, Henri was ostensibly attempting to bolster monarchical power against a traditionally powerful and volatile aristocracy, screening himself against his nearest rivals (his brother François d'Anjou, and the house of Guise-Lorraine). ${ }^{42}$ No such sympathy towards the king emerges in these three sonnets. Instead, Henri is reputedly using his mignons for perverse sexual pleasure; they, for their part, will willingly put their "white-flesh arses” at the king's disposal, if, by the same orifice, they may swallow up as much of the kingdom's wealth as they can. ${ }^{43}$ With this highly obscene emphasis on anal intercourse, together with equally lewd comments on oral, vaginal and masturbatory practices across the sonnet sequence, comes a severe chastisement on its alleged author: Pierre de Ronsard (1524-85). As with the priapic poem of Belleau, L'Estoile 
is only too eager to incline readerly attention towards the degrading scandal of a fallen star. In a scathing commentary L'Estoile denounces the leader of the Pléiade’s flagrant disregard of Christian morality and his equally odious resentment of others receiving royal largesse at his expense. ${ }^{44}$ Lest one doubts that Ronsard is indeed the author, L'Estoile avers that he transcribed the sonnets from "the copy penned by the hand of Ronsard himself as a witness to the uncontainable impiety of this wretched age.”45

Several considerations proceed from this shrill testimony. First is L’Estoile’s autorepresentation of himself as authoritative witness. Foregrounding his powers as a curious collector of manuscripts, he is adamant that this sort of material cannot be contained in any sense through a neutral act of transcribing. Too much is at stake here for this to be merely a recreational exercise; L'Estoile’s remarks imply that he went to considerable lengths to copy the authentic Ronsardian manuscript, with the express design of taking down the leader of the Pléiade. ${ }^{46}$ The transcription therefore must be accompanied by a personal judgement in the form of a pointed disavowal of the transcribed contents. L'Estoile does not condemn Ronsard outright for daring to satirize the king’s manner of rewarding his mignons. Hitherto Ronsard had on several occasions complained about other courtiers (particularly Italian favorites of the Queen Mother) overtaking him in the pecking order for royal gifts. ${ }^{47}$ L'Estoile does not specifically attack these earlier grievances; instead he homes in on what he perceives to be Ronsard's entirely inappropriate manner of protest here, in the guise of an anonymous and excessively spiteful sonneteer.

Besides explicitly condemning obscenity of the crudest kind, L'Estoile’s allegation that Ronsard's verses were barely Christian can be read in two ways. Firstly, in the light of external historical context, it implies a sorely uncharitable attitude on the part of one who had long since been a career churchman (Ronsard took minor orders in 1543). In this context, the further, unstated implication is that L'Estoile is readily undermining the poet's pretences to 
be a credible spokesman of the Catholic Church in his works: a role Ronsard had notably claimed a decade earlier in polemical battles with Protestants over the root causes of France's nascent civil wars. ${ }^{48}$ Then Ronsard had had plenty to say against ecclesiastics obsessed with their worldly goods, and with currying favors at court. ${ }^{49}$ Now it seems that the poet could do no better than heed his own advice on the virtues of unworldliness.

The second interpretation emerges in the context of Ronsard's wider literarytheological orientation. In foregrounding the markedly unchristian character of Ronsard's bitter sonnets, L’Estoile’s remarks could also gesture at Ronsard's complicated and often denounced uses of classical sources. This was not the first time Ronsard had been in trouble for incorporating sexually explicit content via the Ancients. His notorious Livret de folastries (1553) directly alluded on its title page to the lex Catulliana, as if to justify the risqué poems that followed: "Although the pious poet ought to be chaste himself, his poetry need not be so." ${ }^{50}$ Since the 1560 s, moreover, Ronsard had been targeted by Protestants unhappy with the complex syncretistic character of his verse: what Christian symbols and truths were contained therein, they argued, were profaned and obscured by a welter of pagan myths. ${ }^{51}$ In the three obscene Ronsard sonnets recorded by L'Estoile comes another ambivalently profane use of classical mythology, as the poet imagines the king's response to his insinuations:

I know that you will say great Jupiter

In heaven does nothing but fuck arses and cunts,

And yet, for all that, he doesn't lose his crown:

He is mightier on high than you are down here:

He has valiant sons, such is not your case:

Your seed falls on ground that is sterile. ${ }^{52}$ 
Foregrounding Jovian promiscuity and sodomy, these tercets concluding the second sonnet of the triad would appear to be anathema to Christian sexual morality. The base sinfulness of Jupiter’s sex drive was a longstanding element of the medieval Ovid moralisé tradition although it should be noted that some allegorical readings went in the opposite direction, seeing in Jupiter's coupling with his cup-bearer, Ganymede, a strange echo of the Incarnation. ${ }^{53}$ In Ronsard's sonnet, however, the prospect of any redemptive divine-human analogies is conspicuously denied. As Gary Ferguson argues,

we are presented with the possibility that classical legends concerning Jupiter could be read quite literally as tales of nothing other than, and as justifications of, the pleasures of sexual licence. The anticipated tropological application of the stories to the life of the king is frustrated by an alternative representation of the "real": the strength of Henri III's position is not comparable to that of the ruler of the gods; in particular the former is vulnerable as a result of his failure to produce an heir. ${ }^{54}$

For Guy Poirier, Ronsard’s poem nonetheless leaves open the possibility that had Henri been more of a Jupiter - a stronger ruler with robust progeny - his sexual excesses might just have been tolerable. ${ }^{55}$ But as a woeful failure of fecundity, Ronsard's Henri is much closer to Belleau's Jan qui ne peult than to Jove. This time, however, there is not even a whiff of priapic comedy. The king has wilfully made himself infertile as result of his orgies - a far more dangerous condition than Jan's impotence. Not only is the political stability of the realm at stake; the king's very life is also in thrown into doubt. In a syncretistic move, Ronsard passes from Jovian legend to end his second sonnet with a dark biblical allusion. His final allegation of seed falling on sterile ground suggests Onan's practice of coitus interruptus to prevent legitimate offspring: a practice which greatly offended the LORD and which earned Onan an untimely death (Genesis 38:9-10). L’Estoile’s censuring marginal 
commentary gestures obliquely at the latent biblical intertext here. He enjoins readers to see Henri on the brink of divine wrath: through Ronsard’s “barely Christian” verses, the king’s alleged promiscuity, sodomy and onanism become a prime instance of the "uncontainable impiety” L’Estoile sought to record.

Again, L'Estoile's disavowal of his vile materials is questionable. One the one hand, he vehemently chastises Ronsard for insinuating obscenities against the ruler and his court. The implicated corollary is that such sardonic, foul verses are a travesty of one’s Christian duty to flee sexual immorality, to be content with one's estate, and to uphold the monarchy. On the other hand, L'Estoile seems committed to showing how obscene libels might serve as a relevant barometer of a blackening national mood - which he himself acutely experienced. Through post-hoc revisions, the Registre-journal demonstrates the beginnings of an attempt at ordering the uncontainable: a series of social, political and economic upheavals, to say nothing of dynastic uncertainties, all of which seemed to be inextricably linked to immoral royal favoritism. L'Estoile shared his contemporaries' frustrations at their collective inability to change the sovereign's ways; but the memorialist could not openly tolerate their vilest slanders. This tension is still preserved in the layout of the [B] recension of the diaries, where polite, neatly transcribed exhortations against venality are juxtaposed with a shambolic redaction of Ronsard at his most obscene. This clash of two non-verbal forms - two different scribal hands - gives a stark visualization of L'Estoile's notion of desbordement: an overflowing of unrest and anger, where individual gripes merge with commonly-held grievances, and in so doing, overstep the strictures an individual observer might seek to impose upon them. 


\section{Making order in disorder: the ramas and the pasquinade}

L'Estoile's later addition of obscene material in the form of Ronsardian sonnets is atypical of his transcribing tendencies throughout the Registre-journal. This becomes apparent in the light of what would eventually become his dominant strategy for containing sexual (and indeed other forms of) vileness. Across his account of the reign of Henri III, L’Estoile displays a visible pattern of self-censorship with regard to the libellous and obscene ephemera he gathered in great numbers. The tendency towards eventual deletion of obscenities and libels, critics have argued, ${ }^{56}$ is part of the streamlining process whereby L'Estoile worked toward what he hoped would become the definitive copy of the Registrejournal: a version that frankly states the immorality and disorder of Henri III’s reign with minimal explicit and defamatory detail, in short, a version resonant with the politics of forgetting the recent past promoted under Henri IV. It is important to emphasize the importance of textual economy in the later [B] manuscript. Here, the scope of miscellaneous material omitted is by no means limited to morally objectionable pieces: as the historical narrative is streamlined, many more types of curious literary ephemera present in [A] are subsequently left out. Nevertheless, the distinctiveness of censuring and censorial techniques deployed in [A] to contain obscene and slanderous poetry is of much greater significance than has hitherto been suggested, as I shall now argue.

Closely following the venality of offices scandal of April 1578 there came to pass another equally noteworthy upheaval: the sudden death of several of the king's most cherished mignons following a fractious quarrel. What sparked the clash remains decidedly unclear: “a very slender motive” according to L’Estoile, although other contemporary sources say it was on account of certain ladies. ${ }^{57}$ In L'Estoile's testimony, the scene of the duel was the horse market near the Bastille Saint-Antoine (Paris). At 5am on Sunday 27 April, one of Henri’s closest companions, Jacques de Lévis, Comte de Quélus (also spelled Caylus) 
squared up to young Charles de Balsac d’Entragues, Baron de Dunes, known as Entraguet. Both had two high-profile supporters: Quélus was accompanied by François Louis de Maugiron and Jean Duras de Livarot; Entraguet had as his seconds François d’Aydie, vicomte de Ribérac, and Georges de Schomberg. In this furious "Duel of the mignons" L'Estoile reports that only Entraguet escaped with minor wounds; all the others died instantly or soon thereafter. But it did not end there: on 21 July, another leading mignon, the Marquis de Saint-Mégrin, was assassinated by a large group of men, ostensibly at the behest of the Duc de Guise (who also offered protection to the surviving Entraguet). Historians have tended to follow L'Estoile in interpreting these events as part of a broader conflict between the king and the house of Guise-Lorraine: an intensifying struggle played out at this stage through their competing favorites. ${ }^{58}$

Besides the gruesome wounds suffered by the feuding parties, L'Estoile's attention is drawn by the spate of poems commemorating the deaths of those killed in combat. He records more than thirty of these poems in the [A] recension of the Registre-journal. ${ }^{59}$ The tone of such literature is deeply equivocal, as extensive analyses by Gary Ferguson and Guy Poirier have shown. ${ }^{60}$ Written in French and Latin, these intense lyric compositions draw on various ancient models (notably epic and elegiac) to praise Henri’s grief for his slain companions and also to cast it in a dubious moral light. In a more heroic age, the mignons' passing would have been greatly mourned by the people; but as things stand, none except the monarch will shed unseemly, effusive tears. In the words of Ferguson, vilification of the king and of the mignons is thus incorporated by the court poets into verse in their honor, its value transformed, so that it represents what is base, ignoble, ungenerous, unheroic. ${ }^{61}$

The ambiguity of the king's mourning becomes especially marked in various satirical deformations of official poems composed in the mignons' honor. L'Estoile was particularly interested in this kind of satire. A case in point is a pair of poems he records concerning 
Maugiron. ${ }^{62}$ The first is a long, mythological eulogy; the second bears the seemingly innocuous title (presumably of L’Estoile’s own invention) “De lui encore” (“Of him again”), again in reference to the deceased mignon. Both poems describe how Mars and Venus squabble over who gets Maugiron’s beautiful body: in the first, a jealous Mars tries to discourage Venus by gouging out one of the mignon's eyes, and then by killing him outright. In the second, the death of Maugiron is grotesquely implicit. This time, Jupiter calls on his cup-bearer, Ganymede, to settle the dispute: thus Venus gets the front, but it is Priapus, much to Mars’s chagrin, who is allotted the behind. An irate Mars has to settle for Maugiron's soul. Court poets such as Amadis Jamyn had frequently associated Venus and Mars with the mignons; ${ }^{63}$ but the introduction of first Ganymede, and then Priapus, takes this pair of poems from high mythology to obscene, anal sexuality in one fell swoop. As with Jan qui ne peult and Ronsard's filthy sonnets, L'Estoile once again appears to flirt with the classical priapic tradition, this time showing how it might be used to caricature (according to Genette's taxonomy) implicit homoerotic motifs in high mythological registers of eulogy. ${ }^{64}$

But this is only a partial reflection of what L'Estoile is doing here. As in previous instances of obscenity, he rigorously applies his art of containment in an effort to gain critical leverage over the obscene materials he has transcribed. His 1578 collection of mignon eulogies and attendant parasitical satires display the early workings of an ordering process which would soon become the usual pattern for sexual vileness recorded in the $[\mathrm{A}]$ text of the Registre-journal.

The first stage was to group together and section off several poems, thus making them a visible unit within the main body of text. This was a prime tactic of L'Estoile's for grabbing readers' interest. The second stage, which might be mistaken as purely editorial, was to cross out offending poems. L'Estoile used deletion marks sparingly and precisely, with a finenibbed pen; ${ }^{65}$ rarely did he apply more than one or two continuous strokes. Two dominant 
trends emerge, whereby L'Estoile would either superimpose a cross-shaped marking over the transcribed text, ${ }^{66}$ or else a single line down the centre of the poem. In the [A] recension of the Registre-journal, carefully copied obscene texts thus become palimpsests for eyecatching marks and/ or comments of censure; but the text beneath remains legible, intact. It is usually only subjected to a third stage of full censorship, wholesale suppression, in the [B] recension. This three-stage model of textual transformation amounts to more than a set of instructions provided for a third-party scribe charged with streamlining the cumbersome [A] text into the slimmer [B] version. Rather, they reveal much about how L’Estoile used both verbal and non-verbal communication in an attempt to establish - and then consciously work around, if not fully undermine - a regime of self-censorship he struggled to accept fully. These complex strategies of partially disavowing sexual excesses have intriguing parallels with those adopted by contemporary writers such as Henri Estienne and Pierre de Brantôme, as will be shown.

The sheer volume of ephemera responding to fluctuations in the fortunes of the king's mignons provided a stimulus for L'Estoile to develop more elaborate, salient methods of aggregation. After the fateful duel of April 1578, the ensuing groups of mignon poems recorded in the Registre-journal (1578-81) constitute prototypes of a certain kind of collection which, as Schrenck has shown, was to become the hallmark of L'Estoile's compiling style: the ramas. ${ }^{67}$ This is a slippery word: in early modern France it denoted a ragbag assemblage of objects, a "mingle-mangle” 68 of that which seemingly had little intrinsic worth. When applied to miscellaneous collections of writings, or texts which seemed devoid of structure and edifying content, the term ramas often acquired a decidedly pejorative edge in the seventeenth and eighteenth centuries. Voltaire famously dismissed Rabelais's works as “a ramas (hotchpotch) of the most impertinent and gross impurities a drunken monk could possibly spew out.”69 In sixteenth-century France, however, as many 
studies have shown, there was considerable enthusiasm for copious, fragmentary, discontinuous and heterogeneous forms of writing. ${ }^{70}$ L'Estoile shared this humanistic literary penchant for heteroclite material. Ramas was the term L'Estoile used consistently in the Registre-journal from 1585 to 1589 to denote his collections of miscellaneous pieces assembled together at the end of every year, as he transferred his collecting activity from other manuscripts he possessed to the $[\mathrm{A}]$ text of his diary. ${ }^{71}$

Gradually, L’Estoile came to see the ramas as a meaningful repository of waste, and indeed a distinct illustration for his wider enterprise. ${ }^{72}$ Although off-putting to some on account of its proliferating, irksome and usually sordid contents, others - discerning "flâneurs of filth”73 prepared to rummage - might just find insights into the motley mindset of the late sixteenth century. The reader is given full liberty to take the good and discard the bad. ${ }^{74}$ As such, one might situate L'Estoile’s various ramas alongside other embryonic forms of literary miscellany of the period. Thematically, these included notably the anonymous, spiteful Bigarrures folatres et mesdisantes hitherto mentioned. ${ }^{75}$ In the Registre-journal, prior to 1585, instances of the term ramas are rare; but the ragbag structuring principal is clearly already in evidence, and an increasingly important feature of L’Estoile’s efforts to contain sexual vileness. The second group of poems disseminated immediately after the battle of the mignons (April 1578) is not explicitly labelled as a ramas. ${ }^{76}$ It nonetheless exhibits a key formal property that would characterize later ramas collections (fig. 2):

Displayed here is a tapering, "tailpiece” title containing a stern moral pronouncement on the following content. There follows an array of poetic material which bears out this introductory judgement in varying degrees. Through a handwritten, visually arresting triangular paratext ${ }^{77}$ the reader is thus put on the alert to expect the worst: verses that are "scarcely decent, dirty and vile, in the manner of the Court," ${ }^{78}$ in short, the talk of foolish and nasty slanderers. ${ }^{79}$ The following year, in 1579, L'Estoile would intensify these sorts of paratextual, titular 
prompts in a reprise of satirical poems against the mignons: selected highlights from the years 1577-79. ${ }^{80}$ This collection is now duly dubbed a ramas, and it warrants an even more florid tailpiece title (fig. 3):

A particularly striking feature of this paratext is its emphasis on the ramas housing many poems which, for the most part, are "impious and so thoroughly vile, such that the paper blushes at them.” ${ }^{81}$ This striking trope of the blushing paper might at first seem comic, with L'Estoile making light of a prudish sensibility. However, it is unlikely the memorialist intends humor here or in other uses of the same image: each time it appears in his diaries it comes in connection with reports of abhorrent sexual acts. ${ }^{82}$ Parallels may be sought in contemporary writing, with a notable echo in the Apologie pour Hérodote (1566) of the great humanist printer-scholar, Henri Estienne (1531-98). Residing in Calvinist Geneva from 1550, Estienne was, like L’Estoile, an obsessive recorder of sexual scandals, and his particular focus was on those manifested by the clergy. Commenting on a notorious, innuendo-charged sermon, Estienne confesses that he found a particular remark so vile that he preferred not to soil the papier with it. ${ }^{83}$ In fact, Estienne already had. Two versions of the Apologie were published at Geneva in 1566; and in the first, Estienne had included the scandalously coarse jokes about monks and girls mutually impregnating each other. ${ }^{84}$ Before the end of 1566, the Council of Geneva had notified Estienne of their displeasure at certain passages of his work, including this one, whereupon he hastily excised it from the second edition of the Apologie. In so doing, he vehemently defended himself against further accusations of indecency: condemning villains by exposing their despicable behavior, he insisted, was a morally justifiable practice, with solid precedent both recent (the honorable Queen Marguerite de Navarre), and ancient (Xenophon, through his accounts of humiliated drunkards in the Republic of the Lacedemonians, V.4) ${ }^{85}$ Indeed, one only had to turn to a 
fellow Genevan Calvinist, Pierre Viret, to find polemic (De la Vraye et fausse religion, 1560), denouncing so-called abominations in a language as vile as the deeds it recounted. ${ }^{86}$

Estienne clearly resented having to resort to self-censorship to defend his reputation. Like L'Estoile, his preferred method of containing sexual vileness was to expose and then to disavow. In this respect, both authors stressed the aesthetic disfigurement of the very paper inscribed with vile words, so as to impress all the more strongly upon readers the corrosive power of scandalous writing. The stained or blushing paper is a conspicuous sign of an authorial defence mechanism of disgust, an unusually energetic act of "saying no" to the morally vile. As Winfried Menninghaus observes, such stark articulations of disgust imply not just an ability to say no, but even more a compulsion to say no, an inability not to say no. ${ }^{87}$

Menninghaus’s observations on disavowal usefully inform L'Estoile’s practice of compiling obscenities and slanders, more and more frequently in a ramas format. The 1579 ramas of three years' worth of satires against the mignons not only begins with a rhetorically charged condemnation of its contents. It continues with marginal comments by L'Estoile signalling with precision where the especially foul entries begin. Whereas the first seven poems in the ramas had criticized court favorites without name-dropping, and without obscene imagery, the next three reverse these trends, mobilizing explicit allegations of sodomy and buggery levelled against named individuals. Poems 8 through 10 are immediately flagged up as immoral, with the word vilain ("vile”) penned next to them and underscored in L'Estoile's hand: a clear short-hand for personal disgust - and one that draws readers into the offensive sections of the ramas, which they might just recognize already from other satirical compilations. ${ }^{88}$ One-word short-hands would become, as Schrenck has shown, a chief strategy of L'Estoile's, as he simultaneously advertised and disowned his fascination with the vile throughout his diaries. ${ }^{89}$ In the 1579 ramas, the keyword vilain thus 
combines with tailpiece titles and deletion marks in one of the strongest displays of verbalvisual stimuli in all the Registre-journal. The more L'Estoile went about assembling collections of satires of the mignons, the more vociferously he found himself signalling his disgust at his compiled materials. As such, "hate speech” (insults posing a threat to the continued existence of eloquent oratory) was ineluctably prolonged by the very act of transcribing. ${ }^{90}$

Arguably the clearest examples of this double bind are the two long poems recorded in 1579 and 1581, each bearing the title Pasquil Courtizan (Courtly Pasquinade). ${ }^{91}$ Each poem constitutes a quasi-ramas in its own right, introduced by a condemnatory tailpiece introduction, and proffering a relentless, rambling stream of vulgar slanders. The first of these poems is not only classed by the usual short-hand (vilain), but instead is flagged as "filthy, vile and lascivious."92 A notorious offering, it was known to all and sundry at court. Interestingly, it internally thematizes disavowal: the entire piece is framed as the narration of a reluctant calumniator worried that he will get into trouble, but nonetheless goaded by a companion to expose rumors of widespread sexual immorality at the very highest echelons of society. The 1579 Pasquil Courtizan reworks and extends many leading motifs in previously recorded obscene poetry: a sexually voracious Queen Mother, Catherine de’ Medici; mignons resorting to pederasty in exchange for cash; Italian dignitaries accused of sodomy; the naked beauty of the king's slain bosom companions, Quélus and Saint-Mégrin. The master of all villainies is the lascivious king Henri himself, whose bisexual excesses surface on several occasions. Unexpectedly, L’Estoile makes no effort to condemn such defamatory slurs against the sovereign. Instead, he makes them all the more manifest to readers. He inserts two-word marginal comments ("the King”) at three points, ${ }^{93}$ thereby explicating commonly held assumptions about the monarch’s clownish, preening, salacious nature. Once again, L'Estoile enters into a decidedly ambivalent dialog with his text: using supposedly neutral 
short-hands, he intentionally renders even more explicit the very slanders that narrator of this poem ardently hopes will be silenced and not allowed to spread beyond the court. ${ }^{94}$

But there was always more to say. The second Pasquil Courtizan that appeared two years later picks up where the first broke off, and continues in much the same vein - except that it is almost three times as long. The tone of the court-attendant narrator, moreover, has significantly shifted, from reluctance to glee. As Joseph Cady has shown, ${ }^{95}$ the 1581 Pasquil Courtizan scurrilously deploys imagery of marriage to describe a ubiquitous and exclusive homosexuality at Court. The king, it is said, orchestrates the betrothals of his favorite mignons, such as those of the Duc de Joyeuse (whose wedding celebrations in September and October 1581 had been extraordinarily lavish). The "real” nuptials at court, however, are between members of the same sex (man-man / woman-woman). Henri, it transpires, has repudiated his first “bridegroom”, François d'Epinay de Saint-Luc, so that he may pursue homosexual relations with his new lover, Jean-Louis de Nogaret de La Valette. ${ }^{96}$ But it does not end there: instead, the narrator goes on to enumerate with great enthusiasm the king's frenzied liaisons with other men and women. As Una McIlvenna has shown, those defamed include many of the leading lights of the aristocracy, particularly women. ${ }^{97}$ The leering commentary of the 1581 Pasquil Courtizan on these violent sexual pleasures receives an extension in a sequel immediately appended to the poem. ${ }^{98}$ Here, further revelations of perverse copulation are interwoven with familiar complaints about the economic damage to the nation caused by the king's mignons, and the unfair promotions the latter exclusively enjoy. Nevertheless, by this stage there is now nothing newsworthy to report. Eventually tiring of his barrage of libels, the court attendant sums it up thus: "But what more do you want me to say?/ There is nothing more than villainy!”99

If villainy of this sort becomes so reductively tiresome, even to the most committed calumniator, how is one to account for L'Estoile’s insistence on recording it ad nauseam? 
The simplest explanation - and it cannot be ruled out - would be to infer that only a closet delight in obscenity could drive him to establish such monolithic collections of obscene anticourtier slanders. Perhaps the memorialist found the endless cycle of vitriolic hate speech irreverently amusing, making light of the sheer mass of detail contained therein. These considerations notwithstanding, it seems more likely that his attitude towards such profusion was all part of an increasingly conscious counter-attack on the calumniators. As previously demonstrated, L’Estoile was not averse to hitting back at individual poets (such as Belleau and Ronsard) who indulged in vilifying leading public figures and especially the king. In the [B] recension of the Registre-journal, furthermore, a revised summary for the year 1577 shows the memorialist openly taking a stand against libellers (this time Protestant polemicists) en masse. Here L’Estoile’s dating is suspect, since several of his cited examples appeared after $1577 .{ }^{100}$ Historical inaccuracies aside, with hindsight, it became clear to him that the libellers' motives were fundamentally skewed. For L'Estoile, the habit of airing common grievances such as the bombast of the mignons, or the disarray of public finance, was all too often a mere pretext for gratuitous obscenity or vengeance. Far from delivering the much- needed moral tonic, libellers simply tended to aggravate the ailing nation's vices. L'Estoile thus sought to expose patently this wretched process of aggravation, and thereby gain a measure critical leverage over it. The text of his tailpiece introduction is especially instructive in this regard (fig. 4):

This attack on the anonymous author has literary, moral, political and social dimensions. ${ }^{101}$ Firstly, L'Estoile takes a swipe at the poem's outstanding poetic demerits, insisting that its author is in no sense to be ranked among the learned literati. The 1581 Pasquil Courtizan is written in octosyllabic couplets, a highly memorable and popular poetic form of the late sixteenth century associated with farce. ${ }^{102}$ It is clearly not a work of highbrow satire or a multi-layered parody in the same league as Belleau's Jan qui ne peult. Instead, the poet relies 
on any number of cheap shots: for instance, explicit and bestial sexual vocabulary, feeble word-play, and antisemitism. ${ }^{103}$ For L'Estoile, this sort of literary baseness went hand in glove with the prevailing climate of sexual immorality he sought to denounce across his Registre-journal. As previous sixteenth-century moralists had warned, debasement of language and of morals were mutually reinforcing, and this was often interpreted as a sign of God's impending judgement. ${ }^{104}$ L'Estoile goes down this route, suggesting that this pasquinade is a sign that by 1581, sexual sinfulness was at its zenith (although the warning signs had been patently clear for some time). The notion that sin is allowed to increase until it reaches its full measure is biblical, with resonance in both Old and New Testaments (Genesis 15:16; Matthew 23:32).

Yet neither these theological subtexts, nor the overt stereotyping which follows them fully account for the sheer baseness and impudence writ large here. Evoking the longstanding association of uncourtliness, low morals, and low intelligence ascribed to the figure of the foolish villain, ${ }^{105}$ L'Estoile nonetheless avers that the actions of this particular rhymester are irreducible to such commonplaces. The memorialist still considers it unthinkable that any of his (so-called) Christian contemporaries could possibly pen such graphically vile slanders so directly against their divinely elected ruler. Such a remark situates the memorialist struggling to come to terms with the moral and political consequences of unbridled calumny as it now confronts him. For L’Estoile, moderate satire of the sovereign's political failings and even occasional outbreaks of obscenities levelled in his direction might be containable; but this obscenely voluminous pasquinade of 1581 surpassed anything previously seen, even its 1579 prequel. Since the late 1570s, L'Estoile had been keeping a watchful eye on the rising tide of “pernicious” libels and anti-royalist tracts. ${ }^{106}$ His judgment on the 1581 Pasquil Courtizan stands out in an ever more prominently articulated rhetoric of disbelief at the ever bolder attempts to discredit the monarchy that emerged in the final decade of Henri III's reign: a 
period that saw an explosion of obscene slanders, allegations of heresy, atheism, Machiavellianism, and a host of attendant vices pinned on the monarch. Such audacious slurs had surfaced with considerable intensity during the previous decade; they were now becoming the libeller's staple vocabulary for talking about the king and his mignons, ${ }^{107}$ and, in the case of salacious pasquinades, a smoothly iterative discursive mode for arousing collective mirth at their expense.

For L’Estoile, there was no way to obviate this predicament, save to acknowledge, reluctantly, the existence of inordinately villainous libelles - however unpalatable that may be to a Christian writer or reader. The villain rhymester behind the two-part Pasquil Courtizan can only be contained by allowing him to play his full hand across the ramas of the Registre-journal; only then can the memorialist make his move, be it an act of crossing-out, or of verbal moral indictment. L'Estoile duly provides both. Inscribing single, continuous pen strokes through centre of each page of his transcribed text, he adds the summative keyword vilain - at the beginning of the 1581 Pasquil Courtizan, and similarly, at the outset of its lengthy sequel (vilaine et meschante). The memorialist's rhetoric of disgust, one might infer, has also reached its climax.

\section{Scriptural framings of lesbian satire}

Despite its apparently climactic positioning, the two-part 1581 Pasquil Courtizan was by no means L'Estoile's final word on the sexually vile. Admittedly, the long pasquinade left little room for further superlative denunciations; and yet, attempts at such condemnation can still be found in later diary entries of the Registre-journal. ${ }^{108}$ The final section of this article looks at one such attempt: an eye-catching, satirical dialog on lesbian sexuality known as $\mathrm{La}$ 
Frigarelle doing the rounds at Court at the same time as the 1581 Pasquil Courtizan.

L'Estoile situates La Frigarelle immediately after the latter, ${ }^{109}$ and responds with censure and censorial techniques that complement and extend his art of containment.

La Frigarelle (a neologism deriving from the Latin fricare, to rub), details the amorous adventures of a great lady with a young girl. In a customarily severe judgement, L'Estoile tells his readers that the dialog is no less vile than the two pasquinades preceding it. ${ }^{110}$ Subsequent critical reception has been much more diverse. By nineteenth-century standards, this poem was beyond the pale: Gustave Brunet and his fellow editors could not countenance its overt lesbian themes, and omitted all but the title, the first three lines, and L’Estoile’s commentary from their multi-volume edition of L'Estoile, the Mémoiresjournaux. ${ }^{111}$ Modern critics have on the contrary sought to justify the inclusion of $\mathrm{La}$ Frigarelle in their writings, citing it as significant evidence of early modern views on sodomy as same-sex eroticism (Cady); ${ }^{112}$ or as a creative re-writing of elements of lesbian sexual mutuality found in Lucian's Dialogue of the Courtesans, with parallels to contemporaneous works such as Pierre de Brantôme’s Les Dames galantes (Ferguson). ${ }^{113}$

In L'Estoile’s transcription of La Frigarelle, the gossipy Marie gradually prises out of her embarrassed friend Jeanne full details of the latter's venereal pleasures with an older woman who revels in playing the man's part. Jeanne does so only with the utmost reluctance, her face blushing at the very recollection of the vile deed (an image evoking L'Estoile's trope of the mortified paper, ruddily shamed at its own vile contents). ${ }^{114}$ It transpires that Jeanne was solicited into a threesome involving not only the notorious Frigarelle, but also "another lady, one of her companions/ Who disdains such trade still no more than she.”115 Historical candidates have been put forward recently for all three: the Frigarelle could be an allusion to one Anne de Certeau; Jeanne might be a certain Louise de Charansonnet; and the anonymous 
third party could be Diane de France, who was a bastard daughter of King Henri II and an Italian mistress. ${ }^{116}$ In La Frigarelle, Jeanne compounds her embarrassment as she relates how both her newfound bedfellows had their way with her like amorous men; and - worse still she actually began to enjoy the energetic, laddish role-playing of the Frigarelle. ${ }^{117}$ As with his various pasquinades, L'Estoile makes no attempt to suppress the sexual suggestiveness of this poem. Instead, he exercises his usual censorial tactics of crossing out, together with censuring commentary in the [A] recension (the word vilain is writ especially large in the margin). ${ }^{118}$ But this time he goes further still, extending his censure with two pieces of commentary, which together frame the poem and read as an exercise in shaming the composers and readership of material like it.

The crucial, sandwiching effect of L'Estoile's comments is liable to be missed if the focus is primarily on the lecherous figures of the old Frigarelle and her companion preying on a younger woman in the manner of Lucian's macho Megilla character. Judging from his reactions before and after La Frigarelle, L’Estoile’s interests appear less tied to its titillating contents than to how it might affect its readership. Politically speaking, the dialog is perhaps not the most damaging in the memorialist's collections. Unlike the previous two pasquinades, this poem does not directly defame the monarch and named male courtiers, although it ostensibly had the potential to sully the reputation of three high-profile women. L'Estoile, however, is at pains to show that, morally speaking, the damage could hardly have been more inclusive. Introducing La Frigarelle, he notes how it was disseminated widely at Court, and how, just like the preceding Pasquil Courtizan and its sequel, it caused instant mirth wherever it went. But in posterity this would only serve as great shame to the princes and magistrates who avidly immersed themselves in such writings. They did not foresee how their actions would be remembered, 
As if they had tacitly condoned the aforementioned Pasquils describing a sodomite Court, and the vile, unnatural affections of our male and female courtiers, just as we read about them in St Paul, Romans, $1^{\text {st }}$ chapter. ${ }^{119}$

Speaking a Scriptural commonplace into the present circumstances of courtly bawdiness, L'Estoile perceives same-sex desire recounted by the two-part Pasquil Courtizan as essentially continued in La Frigarelle. The same locus (Romans 1:26-27) is expanded and paraphrased immediately after the latter poem:

Women have transformed natural intercourse into that which is against nature; and, abandoning natural intercourse with woman, Men have worked up a heated appetite for one another, Male joining with Male. A vile thing. Romans, $1^{\text {st }}$ Chapter. ${ }^{120}$

Of all the texts hitherto considered, only here does L'Estoile deem it necessary to ventriloquize a biblical author so directly. So why are there not one but two mentions of St Paul here? The answer, I would venture, lies amid interconnected factors: firstly, authorial posture vis-à-vis intended readership, and secondly, experimentation with genre, as I shall now outline. In the first instance, this is an unusually explicit instance of L'Estoile assuming the role of a courageous truth-teller - a pre-Foucalidan parrhesiastes ${ }^{121}$ - declaring uncomfortable biblical truths about the corrupt reading habits of the royal Court and his own professional milieu of parliamentarians. Here, then, lies a barely veiled criticism of his likely readers. And yet, for all his severity, one cannot help wondering whether by 1581 L'Estoile also feared accusations of gross hypocrisy from his peers. He had become, by his own admission, a well-established cog in the network of collectors exchanging lascivious ephemera in and around the Palais de Justice and the Louvre. Hence, by manifestly aligning his own judgement with that of an apostolic authority, L'Estoile signals that he, for one, has 
made precautionary moral adjustments, looking first to Scripture - and only then, through Scripture, at the (homo)sexually vile deeds of the present.

Framed between Pauline allusions to sodomy, the memorialist's transcription of $L a$ Frigarelle and its scandalous lesbian motifs are thus contained, both materially and metaphorically, within an authoritative, biblical framework. Such a framework makes for a much stronger authorial disavowal of lesbian relations than that which may be found in contemporary texts. Brantôme’s Les Dames galantes, a renowned compilation of courtly gossip and sexual proclivities in late sixteenth-century France, ${ }^{122}$ puts forward a number of titillating anecdotes concerning courtly ladies and their female partners: "fricatrices, or those who do the friquarelle as part of the donne con donne trade.” ${ }^{123}$ As David LaGuardia has shown, Brantôme’s overriding concern is to pass critical judgement on rumors about which he is already aware. ${ }^{124}$ The voyeuristic reminiscences of one Monsieur de Clermont-Talland le jeune (a nobleman who had accompanied Henri III in his youth) are of particular interest to Brantôme. Young Clermont-Talland happened to catch sight of two aristocratic ladies conjoined in vigorous, sweaty, coital friction - an encounter not unlike that detailed in L’Estoile's La Frigarelle, and recollected with similar insistence upon women's uncontrollable heat and superabundant desire which transmutes into a powerful imitation of male lasciviousness. ${ }^{125}$

In a move which somewhat parallels Henri Estienne, Brantôme plays up his partial censoring of the Clermont-Talland anecdote, stressing that the latter recounted even more explicit details than he dared record, including the names of the women in question. As Emily Butterworth has shown, Brantôme is always careful to avoid making himself the source of a scandal that would compromise a woman's ability to interact adequately with her community: scandal, described by Calvin in theological terms as a stumbling block to salvation, in Brantôme’s text becomes an obstacle to proper incorporation into the group. ${ }^{126}$ Brantôme 
concludes his account of the Clermont Talland anecdote on a skeptical note, still preferring to suspend judgement on the veracity of his source even after hearing the same tale on many occasions. And yet, the author of Les Dames galantes admits - and one might say enjoys the plausibility of such rumors continually reiterated at Court. The pleasure in verisimilitude here is one that Estienne and L'Estoile manifestly deny. By contrast, Brantôme appears somewhat more relaxed. Despite his discreet censoring, his leisurely musings on lesbians are those of one who insists he is "not their censurer," ${ }^{127}$ but one prepared to look at their sexuality from multiple (masculinist) angles. For Brantôme, gossip about female couplings is not a cue for theological disapprobation; rather it is an opportunity to warn men about worse womanly failings, whoring, cuckoldry and abortion.

L’Estoile will have no such moral latitude. Instead, his biblically oriented critique of La Frigarelle is infused with the outspoken, censuring verve of the placard genre, examples of which he had latterly begun to absorb into the Registre-journal. A particularly salient piece was the "grave and thundering verses” ${ }^{128}$ penned against the king for founding a chivalric Order of the Holy Spirit in January 1579. The placard had been provocatively fastened, L'Estoile noted, on the very doors of the church of the Augustinian Friars in Paris, in full view of the throng assembled for the investiture. The placard opened theatrically with the thundering voice of the Almighty:

\section{GOD SPEAKS:}

You, Princes of Sodom, listen to the LORD:

"Why should I take notice,” said He, “that you honor me

By your many and vain sacrifices?

I am fed up, more than enough, with the sight of your Evildoings!” 129 
Spanning a total of 23 lines, this prophetic paraphrase compresses the first chapter of the Book of Isaiah, which denounces Sodom and Gomorrah. In this pamphlet version, Gomorrah is omitted, as is mention of bull and goat holocausts, swords, New Moons and Sabbaths; moreover, there is no overt development of sodomite themes implicated in the opening address to "Princes of Sodom". Instead, the focus of divine judgement is destruction by fire. As such, the paraphrase becomes a fiery, impersonal satire: one that provides a new social context that frames as a gross act of religious hypocrisy the ceremony performed by the king and his chosen knights. Their over-acted investiture in the new order, one infers, scarcely rights their preceding reputation for debauchery and sodomy which will not escape the Almighty's punishing hand. If there is no moral improvement in the King and his companions, if they do not swiftly learn how to act justly, then they will be given over to everlasting, inescapable fire. The divinely sanctioned death-threats of this Isaiahic prophecy are several rhetorical notches higher than the even the irate pamphlet protests against the royal court following the venality of offices scandal just one year earlier. For L'Estoile, the ominous, impersonal, prophetic tone was now preferable. Indeed, it seemed particularly well suited to the hypocrisy of the age, ${ }^{130}$ and hence worthy of imitation in his framing of $L a$ Frigarelle.

From formal ritual to courtly gossip, L’Estoile continually sought to expose, denounce and distance himself from instances of sexual vileness, foregrounding a perceived culture of moral hypocrisy that fomented such behavior. The seemingly endless supply of new material required a constant re-tuning of his strategies of containment, evolving within the experimental genre of Registre-journal. Scriptural paraphrasing opened up new possibilities for moving beyond emotional outbursts of disgust, into hanging prophetic cadences. And yet, for all their arresting terseness, these direct paraphrases of Scripture wielded against sexual vices remain something of a rarity in the Registre-journal. Perhaps 
this ultimately points to the growing might of a different foe: the Catholic League. Scripture and its (mis)uses would continue to preoccupy L’Estoile, as Paris and the French nation descended into increasing Leaguer-led lawlessness from 1588 to 1594. That period saw the final Valois monarch, Henri III, assassinated (1 August 1589), the League overturned, and a new Bourbon dynasty founded. L’Estoile witnessed much of it first-hand, still leaving visible traces of vileness in all its forms in his sequel volume: the Journal du règne de Henri IV.

\section{Conclusions}

This article has arisen as a response to several unresolved perplexities surrounding Pierre de L’Estoile's censuring and censorship practices: why did L'Estoile continually document obscenities he purported to detest? Why did he not simply excise all trace of them in the latter, streamlined [B] recension of his Registre-journal? And why did he retain a copy of the much fatter [A] recension, in which obscene material is compiled in a large-scale ramas format? The answer I have given to these questions is essentially threefold. Firstly, L'Estoile seems to be documenting, piece by piece, his own eventual realization that sexual vileness could be artfully denounced - but never fully contained. In so doing, he articulates, secondly, a process of legitimating his own inability not to disavow the very objects he has chosen to retain. Thirdly, this process, one might infer, constitutes an elaborate textualization of personal disgust operating on the boundary between conscious patterns of conduct and unconscious impulses. ${ }^{131}$

But L’Estoile’s enterprise does more than simply articulate disgust. Through an impersonal rhetoric of censure it foregrounds the centrality of the censurer - L'Estoile himself - as both obsessive collector and truth-teller, within a discreet network of associates. And yet, L'Estoile was well aware of his own communicative limitations. His writing 
displays telling signs that the ethos of collective discretion he strove to promote was increasingly under threat. Various elements of the Registre-journal give grounds for supposing that L'Estoile was disturbed by recollecting how the free circulation of vile ephemera he had begun to promote in the 1570s had spiralled out of anyone's control by the 1580s. L'Estoile directly witnessed how dangerous obscene pamphlets and poems could be in the wrong hands. Their public utility became severely compromised once they burst out of the courtly and parliamentarian circles that brought them into existence, and spread like wildfire across the whole of Paris and then to the nation beyond. ${ }^{132}$

Unofficial distinctions between the pure and the impure gain an especial impetus in social systems with weakened authorities. ${ }^{133}$ L'Estoile’s disavowal of lengthy, obscene pasquinades points to the increasing ease with which libellers could put salacious courtly gossip to seditious ends. The memorialist's prophetic warnings against obscenity attest his growing fears of divine judgment in the form of insurrection: an ever intensifying emotion with each new outbreak of civil-religious war. Through careful transcription and crossings out, L'Estoile focused readerly attention on the cumulative relevance of what might otherwise be discarded as sterile, literary waste. These non-linguistic manoeuvres operate a vital steer on the procedures of comprehension, insofar as they provide clear constraints on, or strong indications of, the way in which one might infer meaning from the Registre-journal.

In their different ways, L’Estoile, Estienne and Brantôme each imposed a measure of ostentatious self-censorship, as they sought to sidestep the charge of taking a perverse pleasure in gross obscenities. In a brief epilogue to the present study I shall reflect on how convincing their efforts were in the medium term. The seventeenth century, as Joan DeJean has ably demonstrated, ${ }^{134}$ was the age in which mass market printing and an emergent state censorial machinery started to transform obscenity into a permanent social threat. From the early seventeenth century, typeface setters and printers would soon systematically highlight 
coarse words by their minimalist presence: vit (prick) was reduced to v., con (cunt) to c., and foutre (fuck) - the ur-obscentiy - to a telling ellipsis. Censors such as the Jesuit François Garasse (1585-1631) would describe this latter elliptical convention as an act of resistance by the very printing characters themselves. Crediting the materiality of the text with a moral conscience and an agency for expressing a personal disgust, Garasse curiously recalled L’Estoile’s blushing papers. Yet however much officious and official attitudes hardened towards obscene literature, it remained a closeted prize for the canny collector. Through the medium of slippery miscellanies, compilers of obscene verse (recueils satyriques) ironically thematized pointed disavowal of their lewd collections. That which was most forbidden, they knew, was also that which was most ardently sought. Seeing in satire both public correction of vice and a tacit affection for lewdness, the notorious Parnasse des poetes satyriques (Parnassus of Satirical Poets) of 1622 made pointed insinuations that censurers inevitably derived pleasure from the very materials they would condemn. ${ }^{135}$

On this evidence, had L'Estoile lived into the 1620s, and had he continued his habits of disavowing the vile instantiated in his Registre-journal du règne de Henri III, he would have been greeted with mirthful disbelief. For a would-be memorialist, moralist or political commentator, playing the part of the sincere truth-teller was looking less and less like a viable mode of preventing the spread of obscenities - part of the problem rather than the solution. The poets of the Parnasse knew this all too well: an outward show of one's disavowal had become something of a stilted, even amusing, hypocritical formality, perfectly compatible with an inward desire to partake eagerly in the circulation of obscene verses within a secretive cabinet of curious collectors. And yet, should these knowing winks from the next generation of libertins érudits dictate modern readings of L'Estoile? Was he essentially a forerunner of their tongue-in-cheek practices of appealing to censorship to perpetrate the obscene? In the absence of corroborating testimonies from within L'Estoile's 
circle, parallels with the libertins érudits remain indirect. Moreover, to read L’Estoile’s disavowal of the vile as primarily tongue-in-cheek risks understating its power to shock as it entices. From the early seventeenth century, L’Estoile’s sternly censuring works have been read and re-read, sometimes with further editorial censure of their obscenities. This abiding popularity readily attests their ample capacity to offend. Yet it also covertly discloses how an ongoing, obsessive experiment in transcribing and recension ironically transformed forgettable ephemera into memorable collector's items. Continual rediscovery of L'Estoile over the last four centuries attests his importance as a self-aware critic of the vile, torn between discomfort and horrified fascination, as he weighed up whether his filthy materials contained an inherent humor or value. Prefiguring Georges Bataille, L’Estoile’s lasting contribution to the history of sexuality was to show that people are bound and sworn to disavow - even if incompletely - whatever provokes their most intense disgust. ${ }^{136}$

\section{LIST OF CAPTIONS}

Figure 1. Pierre de L'Estoile. Memoires Journaux d'un Curieux. Paris, Bibliothèque nationale de France. Manuscrits: Nouvelles acquisitions françaises 6888, fol. 136 ${ }^{\mathrm{v}}-137^{\mathrm{r}}$.

Figure 2. Pierre de L’Estoile. Registre journal d'un Curieux. Paris, Bibliothèque nationale de France, Manuscrits français 6678, fol $112^{\mathrm{r}}$.

Figure 3. Pierre de L'Estoile. Registre journal d'un Curieux. Paris, Bibliothèque nationale de France, Manuscrits français 6678, fol 149r.

Figure 4. Pierre de L’Estoile. Registre journal d'un Curieux. Paris, Bibliothèque nationale de France, Manuscrits français 6678, fol 179r. 


\section{Bibliography}

\section{Archival Sources}

All manuscript references are cited in the text with the number of the folio.

Bibliothèque nationale de France, Paris (BNF), Cinq Cents Colbert 488, fols. 306 ${ }^{\mathrm{v}}-554^{\mathrm{r}}$. Bigarrures folatres et mesdisantes. Cited as BNF, Cinq Cents Colbert 488.

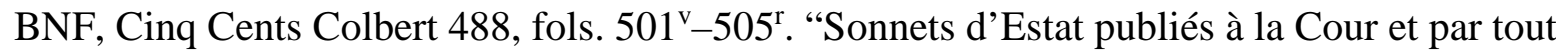
ès Ans 1577 et 1578.” Cited as BNF, Cinq Cents Colbert 488.

BNF, Manuscrits français 6678. Registre journal d'un Curieux. Cited as BNF, MS Fr. 6678.

BNF, Manuscrits français 10304. Recueil divers de ce temps, latins et françois, principalement de Tombeaux curieusement recherchés et ramassés avec autres vers satiriques et discours funebres sur la misere du siecle. Cited as BNF, MS Fr. 10304.

BNF, Manuscrits: Nouvelles acquisitions françaises 6888. Memoires Journaux d'un Curieux. Cited as BNF, MS NAF 6888.

\section{Printed Sources}

Aubigné, Théodore Agrippa d’. Euvres. Ed. Henri Weber, Jacques Bailbé, and Marguerite Soulié. Paris: Gallimard, 1969.

Baranova, Tatiana Debbagi. À coup de libelles: Une culture politique au temps des guerres de religion (1562-1598). Geneva: Droz, 2012.

Birberick, Anne L., Russell Ganim, and Hugh Roberts, eds. Obscenity. EMF, Studies in Early Modern France, vol. 14. Charlottesville, VA: Rookwood Press, 2010. 
Blanchard, M. E. “Fin de Siècle: Writing the Daily at the End of the Renaissance.” In Humanism in Crisis: The Decline of the French Renaissance, ed. Philippe Desan, 23140. Ann Arbor, MI: University of Michigan Press, 1991.

Blanquie, Christophe. Justice et finance sous l'Ancien Régime: La vénalité présidiale. Paris: Harmattan, 2001.

Boucher, Jacqueline. La Cour de Henri III. Rennes: Ouest-France, 1986.

—_. “Contribution à l'histoire du duel des Mignons (1578): Une lettre de Henri III à Laurent de Maugiron.” Nouvelle Revue du Seizième Siècle 18 (2000): 113-26.

—. Société et mentalités autour de Henri III. Paris: H. Champion, 2007.

Boudou, Bénédicte. Mars et les muses dans l’Apologie pour Hérodote d’Henri Estienne. Geneva: Droz, 2000.

Brantôme, Pierre de. Les Dames galantes. Ed Pascal Pia. Paris: Gallimard, 1981.

Braybrook, Jean. Remy Belleau et l'art de guérir. London: Versita, 2013.

Butterworth, Emily. “Defining Obscenity.” In Obscénités renaissantes (2011), 31-37.

—_, and Hugh Roberts, “L’Obscène in French Renaissance Texts.” In Obscénités renaissantes (2011), 87-105.

—. Unbridled Tongue: Babble and Gossip in Renaissance France. Oxford: Oxford University Press, 2016.

Cady, Joseph. “The 'Masculine Love' of the 'Princes of Sodom' 'Practising the Art of Ganymede’ at Henri III’s Court: The Homosexuality of Henri III and His Mignons in Pierre de L’Estoile’s Mémoires-Journaux.” In Desire and Discipline: Sex and Sexuality 
in the Premodern West, ed. Jacqueline Murray and Konrad Eisenbichler, 123-54. Toronto: University of Toronto Press, 1996.

Cameron, Keith. Henri III, a Maligned or Malignant King? Aspects of the Satirical Iconography of Henri de Valois. Exeter: University of Exeter, 1978.

Cave, Terence. The Cornucopian Text: Problems of Writing in the French Renaissance. Oxford: Clarendon Press, 1979.

Cazauran, Nicole. “Henri Estienne lecteur de l’Heptaméron dans l’Apologie pour Hérodote.” In Henri Estienne, 113-28. Cahiers VL Saulnier, vol. 5. Paris: École normale supérieure de jeunes filles, 1988.

Conley, Tom. The Self-Made Map: Cartographic Writing in Early Modern France. Minneapolis: University of Minnesota Press, 1996.

Cornilliat, François, “Obscénité de la poésie: le cas du Livret de Folastries de Ronsard.” Réforme, Humanisme, Renaissance 68 (2009): 29-40.

Cotgrave, Randle. A Dictionarie of the French and English Tongues. London: Adam Islip, 1611.

Courcelles, Dominique de, ed. Ouvrages miscellanées et théories de la connaissance à la Renaissance: Actes des journées d'études organisées par l'Ecole nationale des chartes, Paris, 5-6 avril 2002. Paris: École nationale des chartes, 2003.

Crawford, Katherine. “Love, Sodomy, and Scandal: Controlling the Sexual Reputation of Henry III.” Journal of the History of Sexuality 12 (2003): 513-42.

—. The Sexual Culture of the French Renaissance. Cambridge: Cambridge University Press, 2010. 
Crouzet, Denis. Les Guerriers de Dieu: La violence au temps des troubles de religion (Vers 1525-Vers 1610). 2 vols. Seyssel: Champ Vallon, 1990.

Darnton, Robert. “What Is the History of Books?” Daedalus 113 (1982): 65-83.

Daubresse, Sylvie, Le Parlement de Paris ou la voix de la raison (1559-1589). Geneva: Droz, 2005.

Dauvois, Nathalie. “Des Contreblasons de La Hueterie au Contrepoison d’Artus Désiré, enjeux et formes d’une poétique du contre à la Renaissance.” In Texte et Contretexte pour la période pré-Moderne, Actes du Colloque de Bordeaux, ed. Nelly Labère, 21525. Bordeaux: Ausonius, 2013.

DeJean, Joan. The Reinvention of Obscenity: Sex, Lies, and Tabloids in Early Modern France. Chicago: University of Chicago Press, 2002.

Dubois, Claude-Gilbert. La Conception de l'histoire en France au XVIe siècle (1560-1610). Paris: Nizet, 1977.

Dubost, Jean François. La France italienne: XVIe-XVIIe siècle. Paris: Aubier, 1997.

Estienne, Henri. Apologie Pour Hérodote. Ed. Bénédicte Boudou. 2 vols. Geneva: Droz, 2007.

Ferguson, Gary. Queer (Re)readings in the French Renaissance: Homosexuality, Gender, Culture. Aldershot: Ashgate, 2008.

Ford, Philip. "Obscenity and the lex Catulliana: Uses and Abuses of Catullus 16 in French Renaissance Poetry.” In Obscénités renaissantes (2011), 48-61.

Foucault, Michel. Foucault: Le courage de la vérité. Ed. Frédéric Gros. Paris: Presses universitaires de France, 2002. 
—. Le Gouvernement de soi et des autres: cours au collège de France (1982-1983). Ed. François Ewald, Alessandro Fontana, and Frédéric Gros. Paris: Seuil, 2008.

Frei, Peter. François Rabelais et le scandale de la modernité: Pour une herméneutique de l'obscène renaissant. Geneva: Droz, 2015.

Frisch, Andrea. Forgetting Differences: Tragedy, Historiography, and the French Wars of Religion. Edinburgh: Edinburgh University Press, 2015.

Genette, Gérard. Palimpsests: Literature in the Second Degree. Trans. Channa Newman and Claude Doubinsky. Lincoln, NE: University of Nebraska Press, 1997.

Gravdal, Kathryn. Vilain and Courtois: Transgressive Parody in French Literature of the 12th and 13th Centuries. Lincoln, NE: University of Nebraska Press, 1989.

Greengrass, Mark. Governing Passions: Peace and Reform in the French Kingdom, 15761585. Oxford: Oxford University Press, 2007.

Greffe, Florence, and José Lothe. La Vie, les livres et les lectures de Pierre de l'Estoile: Nouvelles recherches. Paris: H. Champion, 2004.

Hamilton, Tom. “Bigarrures folatres et mesdisantes: A Curio from Pierre de L’Estoile’s Cabinet?” In French Studies Bulletin 37 (2016): 43-46.

—. Pierre de L'Estoile and His World in the Wars of Religion. Oxford: Oxford University Press, forthcoming, 2017.

Heller, Henry. Anti-Italianism in Sixteenth-Century France. Toronto: University of Toronto Press, 2003.

Higman, Francis. "Ronsard’s Political and Polemical Poetry.” In Ronsard the Poet, ed. Terence Cave, 241-85. London: Methuen, 1973. 
Holy Bible, King James Version (1611).

Jamyn, Amadis. Le Second Volume des Euvres. Paris: Robert Le Mangnier, 1584.

Jeanneret, Michel. Perpetuum mobile: Métamorphoses des corps et des œuvres, de Vinci à Montaigne. Paris: Macula, 1997.

—. La Muse lascive: Anthologie de la poésie érotique et pornographique française (15601660). Paris: Corti, 2007.

Jodelle, Etienne. Euvres complètes. Ed. Enea Balmas. 2 vols. Paris: Gallimard, 1965.

Kasprzyk, Krystyna. “Henri Estienne conteur.” In La Nouvelle française de la Renaissance, ed. Lionello Sozzi, 471-80. Geneva: Slatkine, 1981.

Kenny, Neil. The Palace of Secrets: Béroalde de Verville and Renaissance Conceptions of Knowledge. Oxford: Clarendon, 1991.

Knecht, Robert J. Hero or Tyrant? Henry III, King of France, 1574-89. Farnham: Ashgate, 2014.

Kuin, Roger, and Anne Lake Prescott. “The Wrath of Priapus: Rémy Belleau’s ‘Jean Qui Ne Peult’ and Its Traditions.” Comparative Literature Studies 37 (2000): 1-17.

L’Estoile, Pierre de. Mémoires-Journaux de Pierre L'Estoile. Ed. Gustave Brunet et al. 12 vols. Paris: Librairie des bibliophiles, 1875-96.

—. Registre-journal du règne de Henri III. Ed. Madeleine Lazard and Gilbert Schrenck. 6 vols. Geneva: Droz, 1992-2003.

—. Journal du règne de Henri IV. Ed. Gilbert Schrenck and Xavier Le Person. 2 vols. Geneva: Droz, 2011. 
LaGuardia, David P. Intertextual Masculinity in French Renaissance Literature: Rabelais, Brantôme, and the Cent Nouvelles Nouvelles. Aldershot: Ashgate, 2008.

—_. "Henri III et la propagande de l’obscène.” Réforme, Humanisme, Renaissance 68 (2009): 41-52.

—_. “Les journaux de Pierre de l'Estoile: Une cartographie Parisienne.” In Illustrations inconscientes: Écritures de la Renaissance - Mélanges offerts à Tom Conley, ed. Bernd Renner and Phillip John Usher, 419-83. Paris: Classiques Garnier, 2014.

Larcade, Véronique. “Le Duc d’Epernon et les Guises.” In Le Mécénat et l’influence des Guises: Actes du colloque organisé par le Centre de recherche sur la littérature de la Renaissance de l'Université de Reims et tenu à Joinville du 31 mai au 4 juin 1994 (et à Reims pour la journée du 2 juin), ed. Yvonne Bellenger, 547-55. Paris: H. Champion, 1997.

Lazard, Madeleine. Pierre de Bourdeille, Seigneur de Brantôme. Paris: Fayard, 1995.

Le Parnasse des poetes satyriques de ce temps. Paris: Antoine de Sommaville/ Antoine Estoc, 1622.

Le Roux, Nicolas. La Faveur du roi: Mignons et courtisans au temps des derniers Valois. Seyssel: Champ Vallon, 2001.

Lestringant, Frank, ed. Contes et discours bigarrés. Paris: Presses de l’Université ParisSorbonne, 2011.

LHote, Claude, and Claude Troquet. Diane, bâtarde du roi, princesse de la Renaissance. Editions Lulu.com, 2013. 
Marot, Clément. Euvres poétiques complètes. Ed Gérard Defaux. 2 vols. Paris: Bordas, 1990-93.

McGowan, Margaret. “'La Conversation de ma vie’: La voix de L’Estoile dans les Registres/ Journaux.” Travaux de Littérature 3 (1990): 249-59.

McIlvenna, Una. “‘A Stable of Whores’?: The ‘Flying Squadron’ of Catherine de Medici.” In The Politics of Female Households: Ladies-in-Waiting Across Early Modern Europe, ed. Nadine Akkerman and Birgit Houben, 181-208. Leiden: Brill, 2014.

—. Scandal and Reputation at the Court of Catherine de Medici. Abingdon: Routledge, 2016.

McLaren, Angus. Impotence: A Cultural History. Chicago: University of Chicago Press, 2007.

Memory and Community in Sixteenth-Century France. Ed. David P. LaGuardia and Cathy Yandell. Farnham: Ashgate, 2015.

Menninghaus, Winfried. Disgust: The Theory and History of a Strong Sensation. Trans. Howard Eiland and Joel Golb. Albany, NY: State University of New York Press, 2003.

Miernowski, Jan. La Beauté de la haine: Essais de misologie littéraire. Geneva: Droz, 2014.

Mills, Robert. Seeing Sodomy in the Middle Ages. Chicago: University of Chicago Press, 2015.

Montaigne, Michel de, Les Essais. Ed. Jean Balsamo, Michel Magnien, Catherine MagnienSimonin, and Alain Legros. Paris: Gallimard, 2007.

Mousnier, Roland. La Vénalité des offices sous Henri IV et Louis XIII. $2^{\text {nd }}$ ed. Paris: Presses universitaires de France, 1971. 
Nagle, Jean. Un Orgueil français: La vénalité des offices sous l'Ancien Régime. Paris: Odile Jacob, 2008.

Obscénités renaissantes. Ed. Hugh Roberts, Guillaume Peureux and Lise Wajeman. Geneva: Droz, 2011.

Pallier, Denis. Recherches sur l’imprimerie à Paris pendant la Ligue, 1585-1594. Geneva: Droz, 1975.

Parker, Patricia A. Literary Fat Ladies: Rhetoric, Gender, Property. London: Methuen, 1987.

Parkin, Jonathan. “Thomas Hobbes and the Problem of Self-Censorship.” In The Art of Veiled Speech: Self-Censorship from Aristophanes to Hobbes, ed. Han Baltussen and Peter J. Davis, 293-317. Philadelphia: University of Pennsylvania Press, 2015.

Pasquier, Etienne. Choix de lettres sur la littérature, la langue et la traduction. Ed Dorothy Thickett. Geneva: Droz, 1956.

—. Lettres historiques pour les années 1556-1594. Ed. Dorothy Thickett. Geneva: Droz, 1966.

Patterson, Jonathan. Representing Avarice in Late Renaissance France. Oxford: Oxford University press, 2015.

Persels, Jeffery. "Venereal Verse or, For a Reappraisal of the Contreblason.” In On the Margins of French Literature, ed. Henry, Freeman G., 11-20. Amsterdam: Rodopi, 1993.

Petrarch, Francesco. Francesco Petrarca: edizione commentata. Ed. Marco Santagata. Milano: Mondadori, 2004. 
Peureux, Guillaume. La Muse satyrique (1600-1622). Geneva: Droz, 2015.

Poirier, Guy. L’Homosexualité dans l'imaginaire de la Renaissance. Paris: H. Champion, 1996.

—_. "Dialogisme en motif de mascarade: Prolégomènes pour l’étude des discours officiel et polémique sous le règne d’Henri III.” Romanic Review 89 (1998): 37-53.

Polacheck, Dora E. “Brantôme’s Dames illustres: Remembering Marguerite de Navarre.” In Memory and Community in Sixteenth-Century France (2015), 137-48.

Roberts, Hugh. “Obscenity and the Politics of Authorship in Early Seventeenth-Century France: Guillaume Colletet and the Parnasse des poetes satyriques (1622).” French Studies 68 (2014): 18-33.

Ronsard, Pierre de. Livret de folastries, à Janot Parisien. Paris: Veuve Maurice de Laporte, 1553.

—. Oeuvres Complètes. Ed. Jean Céard, Daniel Ménager, and Michel Simonin. 2 vols. Paris: Gallimard, 1994.

Saunders, Alison. The Sixteenth-Century Blason Poétique. Frankfurt am Main: Peter Lang, 1981.

Sawday, Jonathan. The Body Emblazoned: Dissection and the Human Body in Renaissance Culture. London: Routledge, 1995.

Schneider, Robert A. “Self-Censorship and Men of Letters: Tocqueville’s Critique of the Enlightenment in Historical Perspective.” In Tocqueville and Beyond: Essays on the Old Regime in Honor of David D. Bien, ed. Robert M. Schwartz and Robert A. Schneider, 192-225. Newark, MD: University of Delaware Press, 2003. 
Schrenck, Gilbert. “Jeu et théorie du pamphlet dans le Journal du règne de Henri III (15741589).” In Traditions Polémiques, 69-79. Cahiers VL Saulnier, vol. 2. Paris: École normale supérieure de jeunes filles, 1984.

—_. "Pierre de L’Estoile devant ses manuscrits: La fadaise et la sagesse.” Travaux de Littérature 11: Le Manuscrit littéraire: son statut, son histoire, du Moyen Age à nos jours (1998): 95-105.

—_. “Pierre L’Estoile ‘en premieres lignes...’. La poétique du seuil dans Le RegistreJournal du Règne de Henri III.” In L 'Histoire littéraire: ses méthodes et ses résultats: mélanges offerts à Madeleine Bertaud, ed. Madeleine Bertaud and Luc Fraisse, 493502. Geneva: Droz, 2001.

Smith, Helen, and Louise Wilson. Renaissance Paratexts. Cambridge: Cambridge University Press, 2011.

Smith, P. M. "Réalisme et pittoresque dans le journal de Pierre de L’Estoile.” Bibliothèque d'Humanisme et Renaissance 29 (1967): 153-56.

Szabari, Antónia. Less Rightly Said: Scandals and Readers in Sixteenth-Century France. Stanford, CA: Stanford University Press, 2010.

Tabourot, Estienne. Les Bigarrures du Seigneur des Accords. Premier Livre. Ed Francis Goyet. Geneva: Droz, 1986.

Thill, Brian. Waste. London: Bloomsbury, 2015.

Traub, Valerie. The Renaissance of Lesbianism in Early Modern England. Cambridge: Cambridge University Press, 2002. 
Trinquet, Roger. “La Méthode de travail de Pierre de L’Estoile.” Bibliothèque d'Humanisme et Renaissance 17 (1955): 286-91.

Troquet, Claude, and Claude LHote. “Diane de France (b. 1538, d. 1619).” In Dictionnaire des femmes de l'ancienne France. Online. http://siefar.org/dictionnaire/fr/Diane_de_France.

Vickers, Nancy. ““The Blazon of Sweet Beauty’s Best’: Shakespeare’s Lucrece.” In Shakespeare and the Question of Theory, ed. Patricia A. Parker and Geoffrey H. Hartman, 95-115. New York: Methuen, 1985.

Wajeman, Lise. “Usages chrétiennes de l’obscénité.” In Obscénités renaissantes (2011), 393-408.

Wilson, D. B. Descriptive Poetry in France from 'Blason' to Baroque. Manchester: Manchester University Press, 1967.

Voltaire, François Marie Arouet de. Lettres à son altesse monseigneur le prince de **** Sur Rabelais \& sur d'autres auteurs accusés d'avoir mal parlé de la religion chrêtienne. London [i.e. Amsterdam], 1768.

Yardeni, Myriam. “Histoire et petite histoire chez Pierre de L’Estoile.” In Écritures de l'histoire (XIVe-XVIe siècle): Actes du Colloque du Centre Montaigne, Bordeaux, 1921 septembre 2002, ed. Danièlle Régnier-Bohler and Catherine Magnien-Simonin. 193-202. Geneva: Droz, 2005. 


\section{Notes}

${ }^{1}$ Early modern understanding of obscenity moved fluidly between official and unofficial positions of disapprobation and tacit endorsement. The concept evolved from a word group connoting that which was vile, lewd and indecent, servile and base. By the eighteenth century, "the obscene" had become a recognizable, secular legal category of sexually explicit material, tolerated (to a degree) by official state censors. Unofficial attitudes continued to vary from covert curiosity to outright denunciation. Key studies of obscenity in the French early modern period include Roberts, Peureux and Wajeman; Birberick, Ganim and Roberts; Roberts; Peureux; Frei; Jeanneret, 2007; Dejean. In the present study, the term vile (vilain) is the keyword denoting obscenity, and, in some instances, social baseness. On the place of vilain in the nascent semantic spectrum of the obscene, see Butterworth, 2011, 32; more generally, Butterworth and Roberts.

${ }^{2}$ [A] recension: BNF MS Fr. 6678 (Registre journal d'un Curieux); and [B] recension: BNF MS NAF 6888 (Memoires Journaux d'un Curieux).

${ }^{3}$ For holistic studies of L'Estoile’s reading habits, and his contribution to social and cultural history, see Hamilton, 2017; Greffe and Lothe. Important analyses of individual aspects of L’Estoile’s works include LaGuardia, 2014; Szabari; Yardeni; Schrenck, 2001, 1998, and 1984; Blanchard; McGowan; Dubois; P. M. Smith; Trinquet.

${ }^{4}$ Written by L'Estoile and also containing numerous corrections and interventions in his hand, the autograph [A] manuscript constitutes a penultimate draft of the Registre-journal. It was probably composed from 1589 onwards from previous drafts now lost. The stillprovisional text of [A] contains much material subsequently edited out of a later scribal copy [B]. This copy is dated to 1606 at the latest, and seems to have been commissioned for personal use: L'Estoile also intervenes thereupon in his own hand with comments and 
additions. L'Estoile kept the [A] manuscript and even loaned it out to acquaintances curious to go looking further material deemed unfit for [B]. For further discussion of the interrelation of [A] and [B], see L'Estoile, 1992-2003, 1:33-36; Hamilton, 2017, 135-70.

${ }^{5}$ In the light of recent scholarship on memory and community during the civil-religious wars (particularly LaGuardia and Yandell; Frisch) the term memorialist is a more appropriate epithet for L'Estoile than diarist.

${ }^{6}$ L’Estoile, 1992-2003, 1:54.

${ }^{7}$ Ibid: “discrettement, syncerement, sans passion et après leur mort.”

${ }^{8}$ Genette, 1-7; see also Schrenck, 1984, 73.

${ }^{9}$ Szabari, 189-98; Conley, 152. For an alternative use of Conley’s conceptual framing of L’Estoile as a cartographic subject, see LaGuardia, 2014: here L'Estoile is analyzed as mapping himself in relation to the Parisian locations in which he collected his material, according to both totalizing and localizing dynamics.

${ }^{10}$ According to Robert Schneider, the typical features of early modern self-censorship and deliberate obscurantism are: indirection, concealment, obfuscation, dissimulation - in other words, “writing between the lines” (Leo Strauss). See Schneider, 192-225. For further discussion of self-censorship as a form of self-constraint (understood as an individual's voluntary embracing of values that constrain his or her expression) as distinct from selfcensorship by proxy (where individuals feel forced to self-censor in accordance with a dominating agent), see Parkin.

${ }^{11}$ Schrenck, 1998,101.

${ }^{12}$ For details on L’Estoile’s social network, see Hamilton, 2017, 64-93.

${ }^{13}$ L’Estoile, 1992-2003, 2:136.

${ }^{14}$ Ibid. 
${ }^{15}$ L’Estoile, 1992-2003, 2:141-43 (lines 1-4, 18-20, 25, 38-39, 48-49). “Quel desastre nouveau, quel estrange malheur/ Me brasse le Destin, me bannissant de l’heur/ Dont je pensois jouir ceste Nuit pres de celle/ Qui brusle comme moi d'une Amour mutuelle... Mon Vit reste poltron, Mollasse en mesme sorte/ Qu’un boiau replié de quelque Beste morte./ Brief, il reste perclus, morne, lasche et faquin... Flacq, Esquené, transsi, sans Force et sans Vigueur. ... Donq, pour te faire ayser, mon Vit, il te faut ores/ Une Vieille à deux Dents... Un Con baveus, Rongneus, Landreux et Peautreux,/ Renfrongné, Découpé, Marmiteux et Chancreux...” The English translation is from Kuin and Lake Prescott, 6-7.

${ }^{16}$ On impotence literature across early modern Europe, see McLaren.

${ }^{17}$ Gravdal, 39. Here “literary interpretant” is understood as “an existing literary tradition, a well-defined literary silhouette”, which though barely visible at first, "gives shape to the parody, forms its distortion of the intertext.”

${ }^{18}$ Kuin and Lake Prescott, 13.

${ }^{19}$ L’Estoile, 1992-2003, 2:141: “un Tetin ferme et rond, en Fraise aboutissant.”

${ }^{20}$ Marot, 2:241-42 (lines 1-8). On Laura’s shapely breast, see Petrarch, 588-89 (Canzoniere 126, dated to c. 1337). Scholarship on the French blason genre and its Italian influences is extensive. For an overview, see Sawday; Parker; Vickers; Saunders; D. B. Wilson.

${ }^{21}$ Marot, 2:242-43 (lines 1-14). The ugly breast detailed here is “nothing but skin,” "flaccid,” exuding “vile sludge instead of milk”. On the contrastive pairing of the Blason du laid tetin and the Blason du beau tetin, see Dauvois; Persels.

${ }^{22}$ See Ford.

${ }^{23}$ L’Estoile, 1992-2003, 2:140: “vilain et lascif, et mal sonnant aux oreilles chrestiennes.”

${ }^{24}$ Kuin and Lake Prescott, 14.

${ }^{25}$ See Knecht, especially 119-44.

${ }^{26}$ Crawford, 2003. 
${ }^{27}$ L’Estoile, 1992-2003, 2:140-41: “un des doctes et gentils poetes de nostre temps.”

${ }^{28}$ Belleau died on 6 March 1577: hence if he was the author of the poem it would most likely have been among his very last compositions. The modern critic and editor of Belleau's works, Jean Braybrook, finds it highly improbable that this was an instance of his valedictory style (see Braybrook, 78n168). Others are content to let the attribution stand (Kuin and Lake Prescott). For attempts to disambiguate L’Estoile’s copy of the poem from other contemporary manuscript versions of it, see in particular Hamilton, 2016.

${ }^{29}$ L’Estoile, 1992-2003, 2:140-41: “si, à l'exemple de ses compagnons, il n’eust souillé sa muse de telles et semblables vilanies.”

${ }^{30}$ BNF, MS Fr. 10304.

${ }^{31}$ L’Estoile, 1992-2003, 1:149-51.

${ }^{32}$ For Hamilton (2016) the Bigarrures folatres et mesdisantes were perhaps even copied directly from one of L'Estoile's miscellanies that has since been lost, owing to his habit of loaning out collections to friends and acquaintances that were subsequently not returned. ${ }^{33}$ BNF, Cinq Cents Colbert 488, fols. 546-547. See also Jodelle, 1:431-36, 530-33 (“Ten Sonnets Extracted From the Priapée of E. Jodelle”). Of these ten, the first five feature in the Bigarrures folatres et mesdisantes and the remaining five are thematically similar. Like Jan qui ne peult, the penultimate sonnet also featured a decrepit and diseased female body with a hideous vulva: "In going lower, one sees a bloody hole,/ moist skin around a heath which appears/ clothed again in chancres, of sausage filling the edges.” This translation is by Crawford (2010, 191n132), in her analysis of the ten poems (190-91).

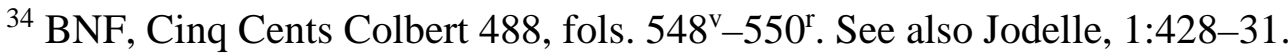

${ }^{35}$ BNF, Cinq Cents Colbert 488, fols. $550^{\mathrm{r}}-551^{\mathrm{v}}$. The introduction reads thus: “A vile and lascivious poem composed by Remi Belleau, one of the most learned and refined poets of our time, as his works do testify; but in this miserable and corrupt age, he would not have been 
considered a truly perfect Poet, if in the manner of his fellow poets he had not soiled his Muse with lascivious and villainous offerings.” (fol. 550 ).

${ }^{36}$ Among the best known contemporaries of L'Estoile to critique the burgeoning problem of venality were fellow jurists Michel de Montaigne and Etienne Pasquier. See Montaigne, 12122; Pasquier, 1966, 244-45, 261. Both raised moral and political objections highlighting the dangers of a justice system controlled by an interested few, with legal judgement acquiring an ever increasing price. On denunciation of venality and greed both within the judiciary and elsewhere, see Patterson; Greengrass; Daubresse; Nagle; Blanquie; and Mousnier.

${ }^{37}$ L’Estoile, 1992-2003, 2:182-87.

${ }^{38}$ Both pieces appear in the Bigarrures folatres et mesdisantes, BNF, Cinq Cents Colbert 488, fol. $503^{r-v}$, in a sub-collection entitled “Sonnets d’Estat publiés à la Cour et par tout ès Ans 1577 et 1578.” According to Dorothy Thickett, both sonnets are the work of Etienne Pasquier (Pasquier, 1956, 109). On satirical attacks on Catherine de’ Medici and her entourage, see McIlvenna, 2016.

${ }^{39}$ See L’Estoile, 1992-2003, 2:182-83: “non par les mains d’un Roy, mais d’une vagabonde”; “un Asne en homme de justice”. The donkey is probably René de Birague, an Italian who had been promoted to Chancellor in 1573. L’Estoile had previously recorded similar anti-Italian slanders against him, "the Donkey of Milan”, as one of a number of Italians benefitting from the largesse of the Queen Mother (L’Estoile, 1992-2003, 1:184). On anti-Italian sentiment in this period, see Heller, Dubost.

${ }^{40}$ L’Estoile, 1992-2003, 2:186-87.

${ }^{41}$ See further Crawford, 2003.

${ }^{42}$ See particularly Le Roux; Ferguson, 147-48.

${ }^{43}$ L'Estoile, 1992-2003, 2:185, 184. On the aggressive penetrative vocabulary associated with anal sex see Cady, 127-28. For more extensive commentary on these sonnets, see 
Ferguson, 133-40; Poirier, 1996, 138-40. On the increasing polemical tendency to attack allegedly obscene behaviour by the king with obscene responses, see LaGuardia, 2009; Ferguson, 171-79; Crawford, 2010, 215-30.

${ }^{44}$ L’Estoile, 1992-2003, 2:185.

${ }^{45}$ Ibid: “[Et les ay doublés] sur la copie de la main propre de Ronsard pour tesmoignage de l’impieté et desbordement de ce malheureux Siecle.” Most modern commentators are content to attribute the sonnets to Ronsard: see for instance the editorial judgment of Céard et al. in Ronsard, 1994, 2:1231, 1246, 1649, 1652.

${ }^{46}$ Alternatively, following the hypothesis of Hamilton (2016), L'Estoile may have copied it from the Bigarrures folatres et mesdisantes.

${ }^{47}$ Since the 1560s Ronsard had been advising the Queen Mother not to over-reward "spongy” Italian courtiers. Moreover, as Ferguson shows (135), in 1569 he had penned an invective elegy excoriating a "Little Mignon Courtier" who monopolises both money and access to the king. In a later poem addressed to the treasurer Nicolas Moreau (c.1573) Ronsard elaborated on the sponge theme, through grotesque images of hypertrophic Italian courtiers relentlessly consuming money, thereby denying more deserving recipients such as himself. See Patterson, 156-58. Poirier $(1996,139)$ suggests that by 1578, Ronsard's chief source of resentment was neither the mignons nor the Italians at court, but the fact that his chief rival, Philippe Desportes, was now the favoured court poet.

${ }^{48}$ See Ronsard's Discours des miseres de ce temps (1562) and subsequent poems in Ronsard, 1994, 2:991-1098.

${ }^{49}$ For example, see Ronsard, 1994, 2:1030 (lines 409-38). Here the poet reminds French prelates of their duties to preach truth and to rebuke vice, exhorting them to stay out of worldly affairs: they should "put off ambition” and "excessive riches”, set aside their worldly grandeur, and be "clothed with virtues and not with silk." 
${ }^{50}$ Ronsard, 1553: “nam castum esse decet pium poëtam/ Ipsum, versiculos nihil necesse est.” This is a direct quotation of Catullus, Carmina 16.5-6. See further Ronsard, 1994, 1:557-71. For studies of obscenity in the Livret de folastries, see Ford; Cornilliat.

${ }^{51}$ See Higman, 258. The Bigarrures folatres et mesdisantes contains a selection of polemics exchanged between Ronsard and his Protestant critics (BNF, Cinq Cents Colbert 488, fols. $\left.334^{\mathrm{v}}, 371^{\mathrm{v}}-377^{\mathrm{r}}, 435^{\mathrm{r}}-437^{\mathrm{v}}\right)$; see also Ronsard, 1994, 2:1059-60.

${ }^{52}$ L’Estoile, 1992-2003, 2:184-5: “Je scai que vous dirés que le Grand Juppiter/ Ne fait rien dans le ciel que Culs et Cons fouter,/ Et que pour tout cela il ne perd sa couronne.// Il est plus fort là haut que vous n’estes ici,/ Il a des Fils vaillans, Vous n’estes pas ainsi,/ Vostre Semence chet en terre qui n'est bonne.” The English translation is from Ferguson, 133. ${ }^{53}$ Mills, 228. The allegory, as Mills argues, was rather daring and far-fetched, transforming an act of sexual violence into an expression of "love”, whereby Ganymede, like Christ, now sits in heaven, performing the role of cup-bearer for God's overflowing grace. In the Renaissance, the figure of Ganymede became a symbol of a sexually passive youth in pederasty: see for instance Cotgrave, s.v. "Ganymedes.”

${ }^{54}$ Ferguson, 133-34.

${ }^{55}$ Poirier, 1996, 140.

${ }^{56}$ See particularly Hamilton, 2017, 135-70.

${ }^{57}$ L'Estoile, 1992-2003, 2:188. For the alternative view that women were the cause, see Le Roux, 391.

${ }^{58}$ Le Roux, 388-416; Boucher, 2000, 113-26.

${ }^{59}$ L’Estoile, 1992-2003, 2:189-99; 226-40.

${ }^{60}$ Ferguson, 147-90; Poirier, 1996, 129-45.

${ }^{61}$ Ferguson, 187.

${ }^{62}$ Here I follow Ferguson, 174-75. 
${ }^{63}$ See for instance Jamyn, fol. 31 ${ }^{\mathrm{v}}$, describing Maugiron as Venus’s foremost love, and as sporting a Mars-like courage.

${ }^{64}$ On caricature as satiric imitation of a particular style, see Genette, 89-98; Ferguson, 178.

${ }^{65}$ Hamilton, 2017, 140.

${ }^{66}$ For examples of this practice, see BNF, MS Fr. 6678, fols. $71^{\mathrm{r}}, 98^{\mathrm{v}}$ (Jan qui ne peult), $100^{\mathrm{v}}$, $111^{\mathrm{v}}$ (defamatory verses against mignons).

${ }^{67}$ Schrenck, 2006.

${ }^{68}$ Cotgrave, s.v. “ramas.”

${ }^{69}$ Voltaire, 3: “un ramas des plus impertinentes et des plus grossiéres ordures qu’un Moine yvre puisse vomir.”

${ }^{70}$ Studies are wide ranging and diverse, covering well-known authors such as Rabelais, Ronsard and Montaigne, and many of their lesser known contemporaries: see for instance Lestringant; Jeanneret, 1997; Cave. On the miscellany, its classical origins and its role in shaping Renaissances conceptions of knowledge, see De Courcelles; Kenny.

${ }^{71}$ Hamilton, 2017, 151.

${ }^{72}$ See Blanchard, 232. On the spatiality of L'Estoile’s organization of his material see LaGuardia, 2014, especially 420 (where L’Estoile is seen as operating “hierarchically,” beginning with published pamphlets from well-known presses and extending down to snatches of improvised public harangues that he heard in the street). Given the fundamentally unsystematic nature of L'Estoile's different ramas, it is unclear to me how his writing style can be described as promoting textual hierarchies.

${ }^{73}$ I owe this expression to Brian Thill's recent study of waste: see Thill, 7-8.

${ }^{74}$ L’Estoile, 1992-2003, 5:53.

${ }^{75}$ Other notable examples of the incipient literary miscellany include Estienne Tabourot's Bigarrures (1582-83). Like L'Estoile's ramas, this work attempted to make a virtue of its 
diversity of subjects “assembled (ramassés) without excessive care” yet still arranged in conformity with an overarching design, like a Turkish carpet. See Tabourot, 1:25. See also Lestringant, 8.

${ }^{76}$ L’Estoile, 1992-2003, 2:191-99.

${ }^{77}$ On similar visual cues offered by tailpieces and related devices in Renaissance print culture, see H. Smith and L. Wilson.

${ }^{78}$ L’Estoile, 1992-2003, 2:191: “peu honnestes, sales et vilains à la mode de la Cour.” ${ }^{79}$ Ibid., 191: "les fous et les meschans.”

${ }^{80}$ Ibid., 3:48-70.

${ }^{81}$ Ibid., 3:48: “impies et vilains, tout oultre, tant que le papier en rougist.”

${ }^{82}$ See also L’Estoile, 1875-96, 9:122, recording instances of child rape “and several other execrable acts, so vile that the paper blushes at their very mention.” Elsewhere the memorialist notes his displeasure at a Jesuit treatise on marriage and its sections on sodomy, depicted "so vilely and abominably, that the paper on which I am writing blushes.” See L’Estoile, 1875-96, 11:87.

${ }^{83}$ Estienne, 1:544.

${ }^{84}$ For details, see Estienne, 1:543-44.

${ }^{85}$ Ibid., 1:544, 2:820. Estienne's source for the Franciscan sermon was the $11^{\text {th }}$ novella in the Claude Gruget edition of Marguerite de Navarre’s Heptaméron, published in 1559. On Estienne’s reading and recycling of stories from the Heptaméron, see notably Kasprzyk; Cazauran. On the Apologie more generally, see Estienne, 1:1-81; Boudou, 2000.

${ }^{86}$ On this and similar "Christian” uses of obscenity in Calvinist polemic, see Wajeman.

${ }^{87}$ Menninghaus, 2.

${ }^{88}$ L’Estoile, 1992-2003, 3:52-55; BNF, MS Fr. 6678, fols. $150^{\mathrm{v}}-152^{\mathrm{r}}$ (poems 8-10). Poems 8 and 9 also feature in BNF, Cinq Cents Colbert 488, fols. $509^{\mathrm{v}}-510^{\mathrm{r}}$ and $506^{\mathrm{v}}-507^{\mathrm{v}}$ 
respectively. Poem 10 (“A Saint Luc (Cats in Cul)”) additionally gains a mention in the works of Théodore Agrippa d'Aubigné, who complains that the anagram of Sainct Luc (Cats in cul) wrongly branded the mignon a sodomite. For d'Aubigné, Saint-Luc constituted a model of repentance for past sins: see d’Aubigné, 605; Le Roux, 436-8.

${ }^{89}$ Schrenck, 1984, 74.

${ }^{90}$ Here I adopt Jan Miernowski’s definition of hate speech (“la parole haineuse”) during the Wars of Religion. See Miernowski, 51-54.

${ }^{91}$ L’Estoile, 1992-2003, 3:56-62, 170-85.

92 Ibid., 3:56: “ord, vilain, et lascif.”

${ }^{93}$ BNF, MS Fr. 6678, fols. $155^{\mathrm{v}}-156^{\mathrm{v}}$.

${ }^{94}$ Here L'Estoile is tacitly referring to his prowess at procuring materials not widely available outside of the Louvre, a suggestion made by Butterworth in relation to the second "Pasquil Courtizan” of 1581. See Butterworth, 2016, 170.

${ }^{95}$ Cady, 127.

96 The latter, soon to be created Duc d'Epernon, would become one of the most powerful courtiers, earning the epithet archimignon (“arch-mignon”). In the late 1580s Epernon was subject to an intense libel campaign again centring on his alleged homosexual relations with the king, drawing an historical parallel with the medieval English King Edward II and his suspected lover, Piers de Gaverston. See Larcade; Cady, 140-41.

${ }^{97}$ See McIlvenna, 2014, 187-88. Those defamed include Antoinette, Comtesse de Châteauvillain, Charlotte de de Beaune, Dame de Sauve; Anne d’Este, Duchesse de Nemours; and Catherine de Lorraine, Duchesse de Montpensier. Leading male targets include Guy du Faur, Seigneur de Pibrac; Anne, Duc de Joyeuse; René de Villequier; the financier mignon François D’O; and Henri, Duc de Guise and his brother Louis, Cardinal de Lorraine. The preponderance of male and female figures here with connections to the Guise-Lorraine 
clan suggests that the author of the 1581 "Pasquil Courtizan" may have had strong antiLeague sympathies.

${ }^{98}$ L’Estoile, 1992-2003, 3:180-85.

${ }^{99}$ Ibid., 3:184: “mais qui veux-tu que je te die?/ Il n’y a plus que Vilanie!”

${ }^{100}$ Ibid., 2:155-56. Three of the most notable pamphlets L’Estoile cites here are Le Cabinet du Roy de France and the Secret des finances (both 1581) by Nicolas Barnaud (under the pseudonym N. Froumenteau); and the famous monarchomach treatise, Vindiciae contra tyrannos (1579).

101 The text reads: "At the end of the year 1581was divulged at Court the following Pasquinade, as clumsily composed and rhymed as it was vile, scandalous and foul. For although excesses of vice had at that time reached their full measure, still there can be no corruption, however great, that could dispose a Christian to slander his Prince and his superiors in quite so degrading and impudent a fashion as that displayed by this villainous, foolish rhymester, the author of these Pasquinades.”

102 McIlvenna, 2014, 188.

${ }^{103}$ L’Estoile, 1992-2003, 3:172, 174, 177, 178: “The King rams his rod up his mignons;” “Madame de Chasteauvillain,/ Having left her villain,/ Chases Monsieur de Guise;” "Dame de la Chastre/ Who's as cold as a sack of plaster,/ Yearning for the c...s of Mules,/ Gets groped instead by her valets;" “See, what a filthy synagogue/ Is our beloved France these days,/ Governed in these filthy ways.”

${ }^{104}$ For a study of such objections made by sixteenth-century critics of Rabelais, see Frei. ${ }^{105}$ On these associations and their roots in medieval literature, see Gravdal.

${ }^{106}$ See for instance L’Estoile, 1992-2003, 2:155.

107 The scholarly literature on these libels is considerable, and much of it deals with the hate campaigns of the Catholic League against the king, particularly in the aftermath of the 
murders of the Duc de Guise and his brother in December 1588. See Knecht; Baranova; Le Roux; Crouzet; Boucher, 1986; Cameron; Pallier.

${ }^{108}$ See for instance, a later ramas offering of “Pasquils” published in 1586 (L’Estoile, 19922003, 5:212-35), detailing debauchery at court that would have turned "the most chaste Lucretia into Faustine” (212).

${ }^{109}$ L’Estoile, 1992-2003, 3:185-89.

${ }^{110}$ Ibid., 3:185.

${ }^{111}$ L’Estoile, 1875-96, 2:54.

112 Cady, 134-35 (including a discussion of whether early moderns saw "sodomy” in any biologically non-procreative sex act). Cady's view is that for L'Estoile and his assumed audience, sodomy overwhelmingly signified only same-sex sexuality. However, counterexamples may be found: as McIlvenna $(2014,188)$ points out, the 1581 Pasquil Courtizan hints at an adulterous, sodomite affair between Mme de Nemours and Guy du Faur de Pibrac. ${ }^{113}$ Ferguson, 290-91.

${ }^{114}$ L’Estoile, 1992-2003, 3:186; 3:48.

115 Ibid, 3:187: “Une autre Dame, une sienne Compagne/ Qui non plus d’elle encore tel mestier desdaingne.”

${ }^{116}$ LHote and Troquet, 216-17. These claims should not be overstated, as the evidence is admittedly slight: two passing allusions in the Registre-journal. The first, found in the A text of the 1581 Pasquil Courtizan (BNF, MS Fr. 6678, fol. $179^{v}$ ), is a marginal annotation in L’Estoile’s hand (“La Frigarelle”) next to the couplet “Charansonnet and her Mistress squeeze themselves together.” The second comes in a later poem in 1585 (L’Estoile, 19922003, 5:144): “Charansonnet is no longer in bloom:/ The bastard woman has grown tired of her; Serteau has deflowered her.” According to LHote and Troquet, this second passage in 
particular evokes how Louise de Charansonnet was passed from an initial lover (Diane de France) to a second (Anne de Certeau).

${ }^{117}$ L’Estoile, 1992-2003, 3:187-88.

${ }^{118}$ BNF, MS Fr. 6678, fols. $183^{\mathrm{r}}-184^{\mathrm{r}}$.

${ }^{119}$ L’Estoile, 1992-2003, 3:185: “comme s’ils eussent advoué tacitement lesdits Pasquils descrivans une Cour de Sodome, et les affections vilaines et contre nature de nos courtizans et courtizannes, telles que nous les lisons en S. Pol aux Romm., Ier chap.”

${ }^{120}$ Ibid., 3:189: “Les Femmes ont mué l'usage naturel en celui qui est contre nature, et les Masles delaissans le naturel usage de la Femme, se sont eschauffés en leur appetit l'un envers l'autre, faisans Masle avec Masle. Chose infame.” Compare Romans 1:26-27 (King James Version): "For this reason God gave them up to vile passions. For even their women exchanged the natural use for what is against nature. Likewise also the men, leaving the natural use of the woman, burned in their lust for one another, men with men committing what is shameful, and receiving in themselves the penalty of their error which was due.” ${ }^{121}$ The figure of the frank truth-teller, the parrhesiastes, is most familiar to the modern critic through the extensive reflections of Michel Foucault: see particularly Foucault, 2008. ${ }^{122}$ Once regarded as little more than unedifying gossip, Les Dames galantes is now increasingly mined by scholars for historically significant reflection on the lives of leading courtiers, and for its many insights into early modern aristocratic sexuality. See Butterworth, 2016; Polacheck; Traub; LaGuardia, 2008; Lazard.

${ }^{123}$ Brantôme, 189: “fricatrices, ou qui font la friquarelle en mestier de donne con donne.”

${ }^{124}$ LaGuardia, 2008, 220-22.

${ }^{125}$ Brantôme, 191-92.

${ }^{126}$ Butterworth, 2016, 150.

${ }^{127}$ Brantôme, 197: “je ne suis pas leur censeur.” 
${ }^{128}$ L'Estoile, 1992-2003, 3:16-17: “vers graves et fouldroyans.” On this pamphlet and its sodomite connotations, see Cady, 135-36. On the investiture and its sexually ambivalent symbolism, see Ferguson, 308-12.

${ }^{129}$ L’Estoile, 1992-2003, 3:17 (lines 1-5): “DIEU PARLE./ Vous, princes de Sodome, escoutés le Seigneur:/ 'Qu’ay-je affaire, dist-il, que me fassiez honneur/ Par la pluralité de vos vains sacrifices?/ Je suis saoul, plus qu’assés, de voir vos Malefices!’”

${ }^{130}$ L’Estoile, 1992-2003, 3:16.

${ }^{131}$ See Menninghaus, 2.

${ }^{132}$ For an extension of this point, see Butterworth, 2016, 166-69.

${ }^{133}$ See Menninghaus (following Mary Douglas), 5.

${ }^{134}$ See particularly DeJean, 29-36.

135 See particularly Roberts, 25-26.

${ }^{136}$ See Menninghaus, following Bataille, 343-56. 